INTER NATIONAL MONETARY FUND
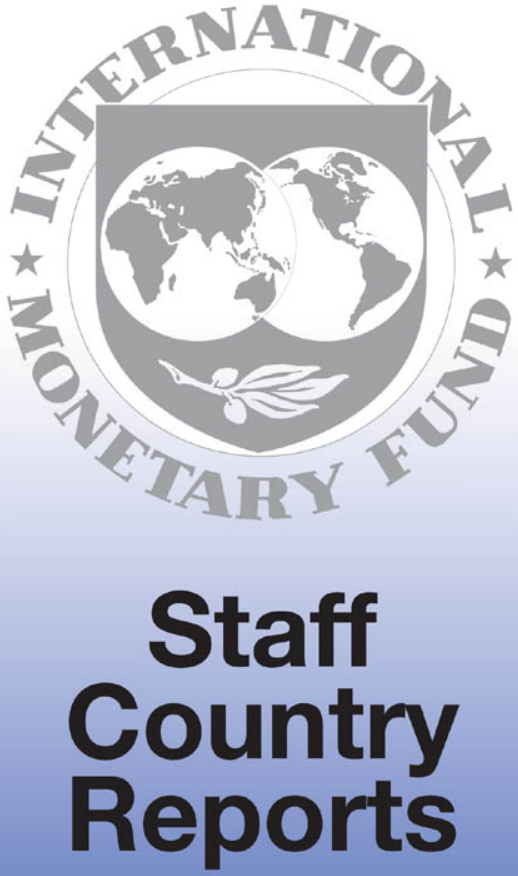


\title{
Burkina Faso: Sixth Review Under the Poverty Reduction and Growth Facility, and Requests for Waiver of Performance Criteria-Staff Report and News Brief on the Executive Board Discussion
}

In the context of the sixth review under the Poverty Reduction and Growth Facility, and request for waiver of performance criteria, the following documents have been released and are included in this package:

- the staff report for the sixth review under the Poverty Reduction and Growth Facility and requests for waiver of performance criteria prepared by a staff team of the IMF, following discussions that ended on September 5, 2002, with the officials of Burkina Faso on cconomic developments and policies. Based on information available at the time of these discussions, the staff report was completed on October 29, 2002. The views expressed in the staff report are those of the staff team and do not necessarily reflect the views of the Executive Board of the IMF.

- a News Brief summarizing the views of the Executive Board as expressed during the November 13, 2002 Executive Board discussion of the staff report.

The document(s) listed below have been or will be separately released

Letter of Intent*

Poverty Reduction Strategy Paper--Progress Report

Joint Staff Assessment of the Poverty Reduction Strategy Paper

*May also be included in Staff' Report.

The policy of publication of staff reports and other documents by the IMF allows for the deletion of marketsensitive information.

To assist the IMF in evaluating the publication policy, reader comments are invited and may be sent by e-mail to publicationpolicy aimf,org.

Copies of this report are available to the public from

International Monetary Fund - Pub́lication Services

70019 th Street, N.W. $\bullet$ Washington, D.C. 20431

Telephone: (202) 6237430 - Telefax: (202) 6237201

E-mail: publications@imf.org * Internet: http://www.imf.org

Price: $\$ 15.00$ a copy

\author{
International Monetary Fund \\ Washington, D.C.
}




\title{
INTERNATIONAL MONETARY FUND
}

\author{
BURKINA FASO
}

\section{Sixth Review Under the Poverty Reduction and Growth Facility, and Request for Waiver of Performance Criteria}

Prepared by the African Department

(In consultation with the Fiscal, Legal, Monetary and Exchange Affairs, Policy Development and Review, Statistics, and Treasurer's Departments)

Approved by Amor Tahari and Martin Fetherston

October 29,2002

Contents

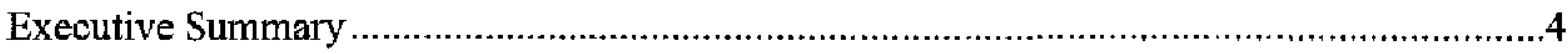

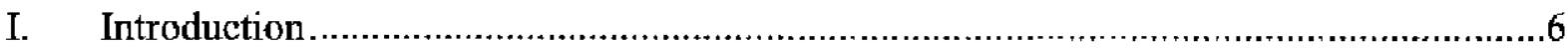

II. Economic Developments and Program Implementation Through June 2002 .................7

A. Growth and Inflation...............................................................................

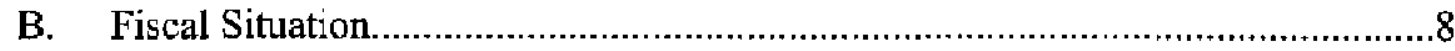

C. Money and Credit.....................................................................................10

D. Structural Reforms and Governance ..........................................................10

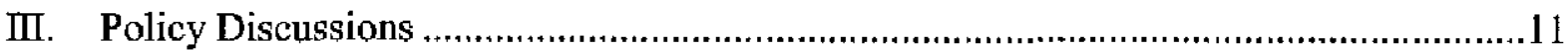

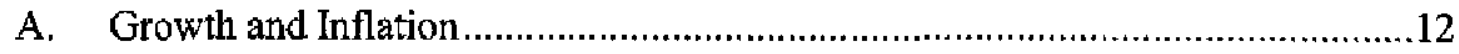

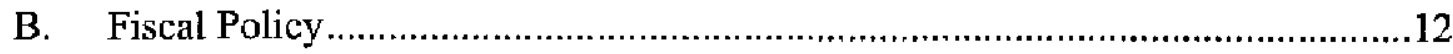

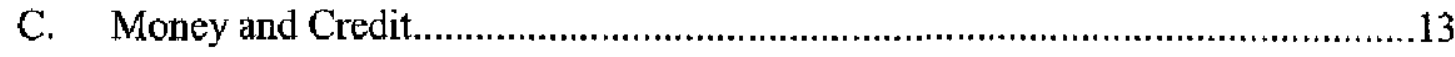

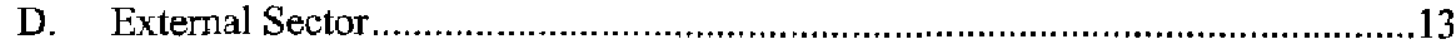

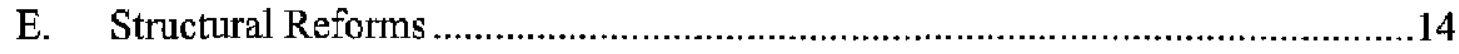

F. Medium-term framework............................................................................14

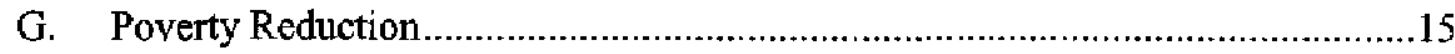

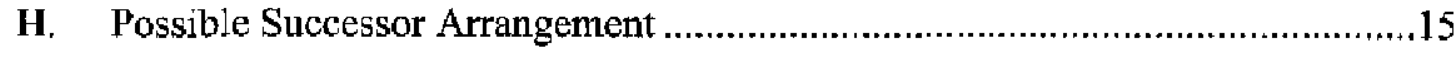

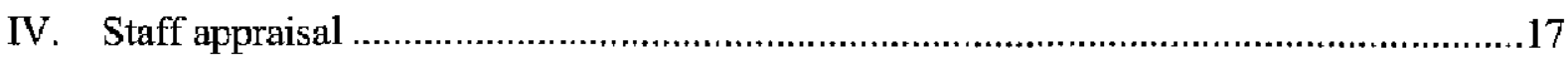


Boxes

1. Experience with the Absorption of Resources Freed by Debt Relief .........................

2. Structural Reforms Under the PRGF-Supported Program .................................11

3. $\quad$ Recent Trends in Burkina Faso's Trade Patterns.................................................16

Figures

1. Real and Nominal Effective Exchange Rates, January 1990-June 2002 .................... 19

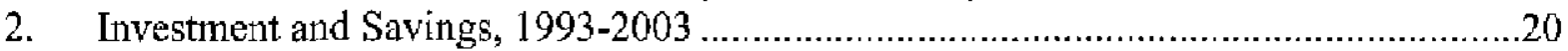

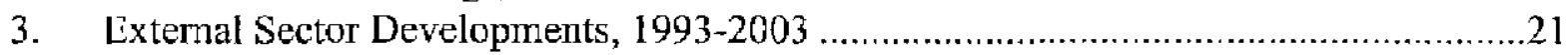

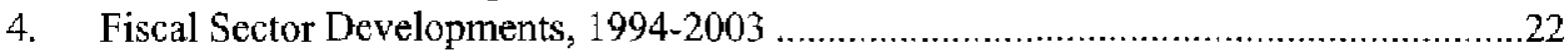

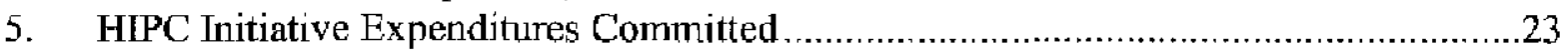

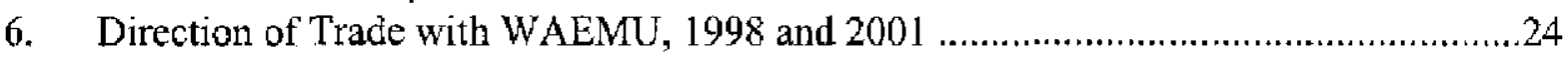

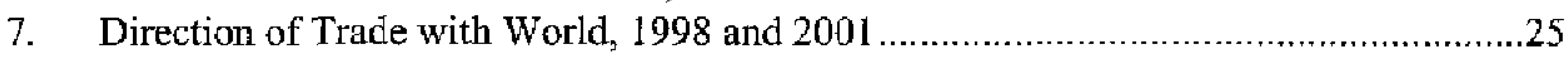

Tables

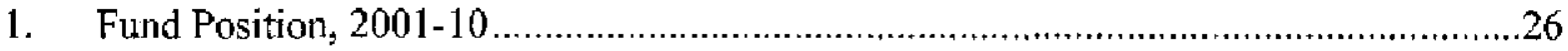

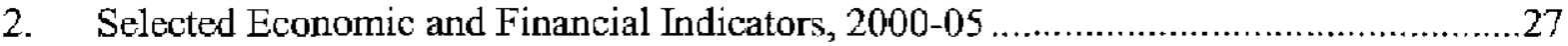

3. Consolidated Operations of the Central Government, 2001-05 ............................28

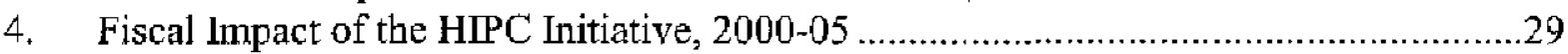

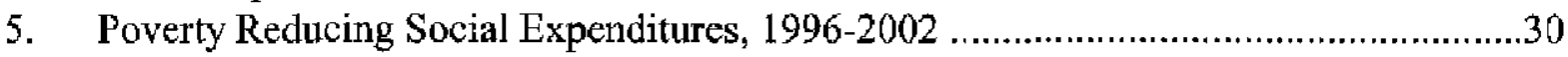

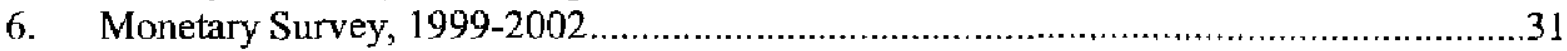

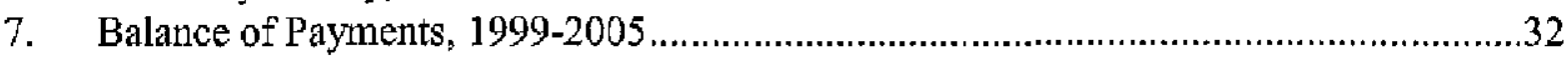

8. Tracking Delivery of HIPC Initiative Assistance-

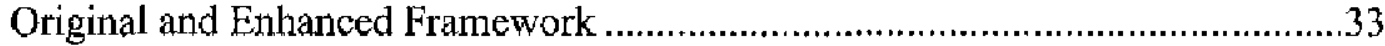

9. Implementation Status of Actions to Strengthen Tracking of Poverty-Reducing

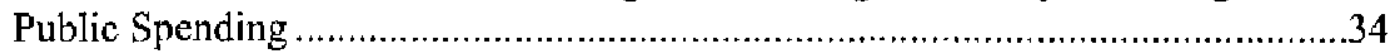

Appendices

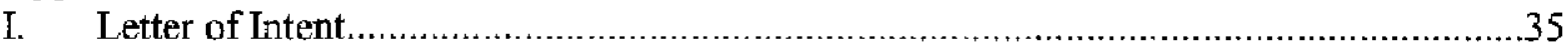

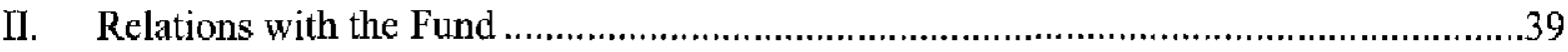

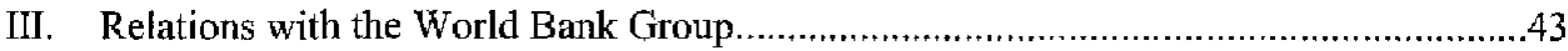

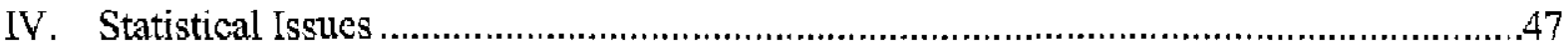

V. Elements of a Successor Program That Could be Supported by a Three-Year

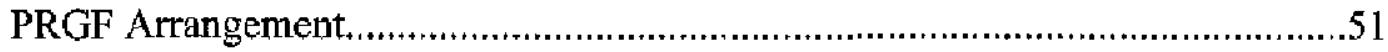


- A staff team visited Ouagadougou from August 26 to September 5, 2002 to conduct discussions on the sixth review of Burkina Faso's current three-year arrangement under the Poverty Reduction and Growth Facility (PRGF). The Burkinabè authorities have agreed to publish the staff report following its consideration by the Executive Board.

- The staff team comprised Mr. van den Boogaerde (head), Ms. Adenauer, Ms. Maechler, and Mr. Ossie (all AFR). Mr. Thiam (AFR) participated in the second half of the mission. Mr. Franco, the Fund's Resident Representative in Burkina Faso, participated fully in the mission, as did Mr. Walliser from the World Bank. The mission met with Prime Minister Yonli; Minister of Finance and Budget Compaore; Mr. Zalle, the National Director of the Central Bank of West African States (BCEAO); and other senior officials. The mission also met with the Ministers of Health, Education, Justice, Economy and Development, and others.

- The PRGF arrangement, in an amount equivalent to SDR 39.12 million (65 percent of quota), was approved on September 10, 1999. A three-month extension of the arrangement until December 9, 2002 was granted to Burkina Faso in order to allow an orderly completion of the sixth review. The fifth review was completed on April 9, 2002, and total disbursements under the arrangement equal SDR 33.54 million. As of endAugust 2002, Burkina Faso's outstanding use of Fund resources amounted to SDR 92.5 million (equivalent to 153.7 percent of quota).

- Burkina Faso has accepted the obligation of Article VIII, Sections 2, 3, and 4, and maintains an exchange system free of restrictions on the making of payments or transfers for current international transactions. 


\section{EXECUTIVE SUMMARY}

- The implementation of the PRGF-supported program remains largely satisfactory, with all but one of the quantitative benchmarks and indicators for end-March 2002 met, and all but two of the quantitative performance criteria, benchmarks, and indicators met at end-June 2002. The performance criterion on total net budget financing and the indicator on the ceiling on current government expenditure were not met at end-June, reflecting mainly the larger subsidies placed on petroleum products in response to higher-than-expected international petroleum prices, and higher-thanprogrammed outlays for the May 2002 legislative elections. The end-June structural performance criterion on the appointment of judges to the Supreme Audit Court was observed, but the performance criterion on the elimination of the remaining administratively set customs valuations was not met.

- Real GDP growth is estimated at 5.6 percent in 2001, while inflation remained subdued, with the year-on-year consumer price index increasing by 1.7 percent in July 2002 . The real effective exchange rate appreciated by 6.7 percent over the 12-month period through June 2002, largely on account of the depreciation of the U.S. dollar against the euro, to which the CFA franc is pegged.

- There was a marked acceleration in the commitment of HIPC Initiative resources to make up for the spending delays incurred during the past year. The uncommitted balance of HIPC Initiative resources provided in 2000 and 2001 was fully committed by endSeptember 2002. A HIPC Initiative account was opened by the treasury at the central bank early in the year to increase transparency and ensure the availability of resources.

Prospects through end-2002

- Real GDP is projected to grow at the same rate as the previous year, reflecting a more conservative forecast for the cotton harvest, while inflation should remain subdued. The current account deficit (excluding grants) is expected to narrow to 14.5 percent of GDP in 2002 (11.5 percent of GDP, including grants) from 15.1 percent ( 11.9 percent) in 2001 .

- Regarding the public finances, the primary objective for the remainder of 2002 is to consolidate the fiscal position. Additional efforts to increase tax collection and measures to combat tax evasion, coupled with expenditure cuts in nonessential goods and services, as well as transfers, should partly offset the expenditure overrun in the first half of the year and larger subsidies for petroleum products that would result from the high level of international oil prices expected through December 2002. The overall deficit (commitment basis, including grants) should be contained at 6.4 percent of GDP (5.9 percent of GDP under the original program).

- A progress report on the second year of implementation of the poverty reduction strategy paper (PRSP), presented together with a joint staff assessment, was prepared in May-June 2002 and discussed with representatives of civil society and donors during a 
two-day seminar in July. The report presents the results obtained in 2001 and lays out the measures the government is planning to pursue in 2002-03 in order to achieve its poverty reduction objectives.

- The authorities have indicated that they will request a successor PRGF-supported program in early 2003 to consolidate the gains achieved in an uncertain international environment under the present program. The main aim of this program, with a view to preparing an exit strategy, should be to devise specific ways to accelerate growth.

\section{Staff appraisal}

- Burkina Faso continued to execute its three-year PRGF-supported program in a generally satisfactory manner. The prudent management of the cotton sector in the face of low international prices resulted in a record crop and a significant increase in farmers' incomes without recourse to subsidies. The ensuing multiplier effects allowed for a relatively high growth rate, in line with the country's poverty reduction objectives. The authorities should persevere with such flexible policies, while making special efforts to further diversify the economy. The structural reform program remains adequate and attuned to Burkina Faso's needs, but it needs to be pursued vigorously.

- For the first time in two years, the authorities were able to reverse the decline in tax revenue. However, the bulk of this positive outcome is due to a good performance in taxes on international trade, with a less-than-satisfactory outcome for domestic direct and indirect taxation. The expenditure overrun in the first half of 2002 is regrettable, although explained in part by exogenous factors and the cost of elections. The authorities have already identified corrective measures, and the staff is confident that the budget can be brought back on track by year's end. Nonetheless, this situation confirms the need to pursue fiscal consolidation with steadfast determination this year and in the medium term by continuing to increase revenues and to limit nonessential outlays, so as to generate savings that can be redirected toward the domestically funded investment program and the social sectors.

- The authorities should be commended for continuing to pursue the poverty reduction objectives embedded in their PRSP, for having increased the budgetary outlays in the social areas, and for significantly accelerating the commitment of HIPC Initiative resources to make up for the slow start during the past two years. These efforts should be pursued, in particular by addressing the remaining absorption bottlenecks, by continuing to broaden the participatory process, and by improving the tracking of social outcomes. 


\section{INTRODUCTION}

1. In the attached letter of intent, the authorities review the performance under the Poverty Reduction and Growth Facility-(PRGF) supported program and describe the policies that will be implemented through December 2002 (Appendix I). A progress report on the second year of implementation of the poverty reduction strategy paper (PRSP) was prepared in July 2002 and will be issued separately, together with a joint staff assessment.

2. In April 2002, the IMF and World Bank Boards agreed that Burkina Faso had fulfilled the conditions for reaching the completion point under the enhanced Heavily Indebted Poor Countries (HIPC) Initiative. It was also agreed to grant Burkina Faso exceptional debt relief (topping up) to achieve debt sustainability and mitigate the adverse effect of terms of trade shocks on Burkina Faso's debt ratios. ' Paris Club creditors agreed in June 2002 to grant Burkina Faso a stock treatment on Cologne terms. ${ }^{2}$ They also committed themselves to topping-up relief and additional bilateral debt forgiveness, but they have not yet reached a consensus on the methodology for delivering this assistance. Meanwhile, the authorities are seeking the participation of its non-Paris Club bilateral and multilateral creditors in the HIPC Initiative.

3. The 2002 Article IV consultation was concluded on April 9, 2002. On that occasion, Executive Directors commended the authorities for their continued sound economic policies and progress in structural reforms, in particular their prudent management of the cotton sector. They stressed the need to maintain steady and rapid growth, strengthen the external position, and achieve durable poverty reduction.

4. The World Bank approved a second Poverty Reduction Support Credit (PRSC II) for Burkina Faso in July 2002 in an amount of US\$35 million. It has supported Burkina Faso's reform program since the early 1990 s through a number of project and sector credits, with a total cumulative disbursement through end-August 2002 of US\$91 million. Summaries of Burkina Faso's relations with the Fund and the World Bank Group are presented in Appendices II and III.

5. Burkina Faso's economic and financial statistical database is adequate, but further work is needed to improve the quality and coverage of statistical information. The authorities are addressing these issues, notably in the area of public finances. Moreover, the country has

\footnotetext{
${ }^{1}$ Including the topping-up, the total nominal debt-service relief provided under the HIPC Initiative equals about US\$930 million. The Fund's share of the topping-up assistance remains undisbursed as satisfactory financing assurances are not yet in place.

${ }^{2}$ It provided for the cancellation of 87 percent of remaining pre-cutoff-date commercial claims (US\$22 million).
} 
achieved full participation in the General Data Dissemination System (GDDS). Statistical issues are summarized in Appendix IV.

6. Legislative elections were held in Burkina Faso on May 5, 2002. For the first time, all opposition parties participated in the elections, which were judged to be fair by international observers. The ruling party obtained 57 out of the 111 seats in parliament ( 51 percent), with the remaining seats going to representatives of 13 different parties. Prime Minister Paramanga Yonli was reappointed in June 2002, and the former Deputy Minister of Finance, Jean-Baptiste Compaoré, was promoted to Minister of Finance. The new eabinet comprises 26 ministers, of which 3 ministers are not members of President Compaorés Congrès Pour la Démocratie et le Progrès (CDP) party.

\section{Economic DeVelopments ANd Program ImPlementation Through June 2002}

\section{The implementation of the PRGF-supported program remained largely}

satisfactory. All quantitative benchmarks for end-March 2002 were met, but the indicator on the ceiling on current government expenditure was not met. Except for the quantitative performance criterion on total net budget financing and the indicator on current government expenditure, all the end-June 2002 quantitative performance criteria, benchmarks, and indicators were met. The nonobservance of the performance criterion on total net budget financing was caused by expenditure overruns, largely due to higher outlays prior to the May 2002 legislative elections, and to larger subsidies on cooking oil, butane gas and petroleum product deliveries to the electricity company-a response to higher-than-expected international petroleum prices. The end-June 2002 structural performance criterion on the appointment of judges to the Supreme Audit Court was observed. However, the performance criterion on the elimination of the remaining administratively set customs valuations was not observed, because the authorities took advantage of a May 2002 directive of the West African Economic and Monetary Union (WAEMU) asking member countries to submit requests for extensions of existing customs valuations to the World Trade Organization (WTO). The authorities have requested waivers for the two performance eriteria that were not observed, based on the fact that the slippages were relatively minor and corrective actions have been taken as discussed below.

\section{A. Growth and Inflation}

8. Real GDP growth is estimated at 5.6 percent in 2001, somewhat lower than previously projected owing to a slight downward revision of cotton production. ${ }^{3}$ The record cotton production resulted in the primary sectors growing by 7.1 percent, with more modest

\footnotetext{
${ }^{3}$ The GDP series for 1993-2002 was revised upward to bring it in line with the authorities' final GDP data for 1993-98. Programmed and actual numbers in percent of GDP are thus not easily comparable.
} 
growth in the secondary and tertiary sectors, of 3.3 percent and 4.6 percent, respectively. Inflation remained subdued, with the year-on-year consumer price index increasing by 1.7 percent in July 2002. The real effective exchange rate appreciated by 6.7 percent over the 12-month period through June 2002, mainly owing to the weakening of the U.S. dollar against the euro, to which the CFA franc is pegged.

\section{B. Fiscal Situation}

9. Fiscal performance in the first half of $\mathbf{2 0 0 2}$ was generally satisfactory. Revenue was above target for end-March 2002, mainly driven by customs receipts, while the programmed ceiling on current expenditure was not respected (Table 3). At end-June, revenue continued to over perform relative to the target, reflecting mainly a good performance of tax receipts on international trade, which, in turn, benefited from a simplification of procedures and enhanced customs controls. Expenditure on wages and salaries was kept below the programmed level. However, outlays for goods, services, and transfers were well above target. The overrun on goods and services reflects the bringing forward of certain outlays and the rapid commitment of HIPC Initiative-related resources. Also, the noncentral government entities incurred an unscheduled deficit. The larger-thantargeted level of transfers was mainly due to transfers to the electricity company on account of larger subsidies on fuel for electricity production, in response to higher-than-forecast international petroleum prices, and because outlays for the May 2002 legislative elections were higher than originally planned. ${ }^{4}$ Finally safety net outlays, consisting of subsidies on the prices of cooking oil and butane gas, were above target. These factors led to an overall fiscal deficit for the first half of the year (commitment basis, including grants) of 3.4 percent of GDP (5.2 percent of GDP excluding grants), compared with a target of 3 percent of GDP.

10. The authorities were able to reduce the float of expenditures committed but not paid by CFAF 5.7 billion by end-June 2002. There was a significant accumulation of deposits at the treasury by parastatal enterprises-CFAF 22 billion, or 1.1 percent of GDP. These parastatals are expected to run down their deposits during the course of the year. All in all, the deficit on a cash basis stood at 1.8 percent of GDP at end-June 2002, which was financed by foreign resources in line with projections and a successful launch of treasury bills on the regional market. However, the performance criterion on the total net domestic budget financing was not observed, owing to lower-than-expected nonbank financing.

11. There was a marked acceleration in the commitment of HIPC Initiative resources to make up for the spending delays incurred during the past year (see Box 1 for an analysis of Burkina Faso's absorption capacity). The program called for spending 80 percent of the

\footnotetext{
${ }^{4}$ These outlays consist, inter alia, of transfers to the independent national election committee for the hiring of poll workers and printing of ballots, the press, and the political parties so that all parties would be on the same footing to purchase leaflets and airtime.
} 
noncommitted balance of HTC Initiative resources provided in 2000 and 2001 (estimated at CFAF 22.5 billion at end-December 2001 ) by March 15, 2002, and the balance by April 30 , 2002. This goal was achieved: CFAF 20.3 billion was committed by end-March 2002 (with CFAF 20.1 billion committed by March 15), and 23.4 billion was committed by endApril 2002. Moreover, the program called for half of the residual amount to be effectively paid by June 30, 2002; this goal was nearly met, with CFAF 10.7 billion ( 48 percent) disbursed by that date. Also, a HIPC Initiative account was opened by the treasury at the central bank early in the year to increase transparency and ensure the availability of resources. Because of this, averall poverty-reducing spending is expected to increase by 1.8 percent of GDP in 2002 (Table 5). The spending financed by non-HIPC sources is projected to remain stationary in nominal terms (hence declining somewhat as a share of GDP) essentially because of the finalization in 2001 of a large World Bank-funded project in the health sector.

\section{Box 1. Burkina Faso: Experience with the Absorption of Resources Freed by Debt Relief}

Burkina Faso received CFAF 7.1 billion ( 0.4 percent of GDP) in debt relief through the HIPC Initiative in 2000, and CFAF 26.5 billion in 2001 ( 1.5 percent of GDP). However, no HIPC Initiative-related expenditure was committed in 2000, and only CFAF 6.6 billion was committed in 2001, accounting for only 19.6 percent of the total available tesoutces. On a cash basis, HIPC Initiative-related expenditure was even lower, The reasons for Burkina Faso's absorption problem were institutional weaknesses, as well as physical bottlenecks beyond the government's control.

Institutional constraints arose because the set up of the three-tier set of committees to execute and monitor social expcnditures, created in June 2000, was perhaps too sophisticated: a ministerial oversight committee, chaired by the Prime Minister, is the decision-making body of PRSP implementation; an interministerial technical monitoring committee coordinates the implementation of sectoral action plans; and a third set of sectoral monitoring groups is responsible for implementing the PRSP within ministerial departments. This structure did not become fully operational because of certain weaknesses, such as irregular meetings of sectoral groups and confusion about their role, as well as the lack of clear sectoral policies at the ministry level for the allocation of resources to reduce poverty. Moreover, it proved difficult to determine which expenditures were effective in helping the poor, to smooth the allocation of resources over a longer period of time, and to involve a variety of stakeholders in the process.

Physical bottlenecks emerged because poverty reduction expenditure is most strongly needed in rural areas, where basic infrastructure is often lacking. In the absence of basic physical and financial infrastructure, exogenous shocks in the form of poor weather conditions hampered construction works, including the construction of schools and rural roads, which, in tum, delayed disbursements. Moreover, the decentralization process has not yet resulted in a fully operational decentralized administrative structure that would allow for an efficient and swift execution of poverty-reducing projects in remote areas of the country. Finally, budgetary disbursement procedures had to be adapted to facilitate disbursements at the local level, while ensuring proper tracking.

Overall, important progress has been made, but more work is needed to increase Burkina Faso's absorption capacity and ensure that the poor fully benefit from the increased budgetary allocations to the social sectors and debt relief brought about by the HIPC Initiative. A significant acceleration of social expenditures, funded with debt relief under the HIPC Initiative, was achieved in the first half of 2002, and the government is actively reforming its budget planning and management. Moreover, the government has launched a comprchensive decentralization program. Finally, the govcrnment is now committed to making the PRSP-related institutions fully operational by addressing the remaining weaknesses. 


\section{Money and Credit}

12. During the first half of 2002 , broad money grew by a very modest 1.1 percent (Table 6). There was an accumulation of CFAF 11 billion in net foreign assets, reflecting the proceeds of the sale of the 2001-02 cotton crop. Net credit to the government declined by 2.3 percent of beginning-of-period money stock, allowing for a higher-than-programmed growth to the economy. However, all of this increase was tied up in credits to the cotton sector, which grew by 17 percent from end-December 2001, whereas noncrop private sector credits declined by 6 percent over the same period. While a lower level of government indebtedness allowed for an influx of private deposits in commercial banks, there is clearly a growing problem of allocating loanable funds to the private sector. In May 2002, the authorities successfully placed their first issue of treasury bills on the regional market, using a three-month maturity.

13. Banks are broadly complying with key prudential ratios of the regional banking commission. As of end-June 2002, six of the seven banks were complying with the 8 percent risk-weighted capital ratio, that is, one more bank than at end-2001. As before, none of the banks comply with the portfolio structure ratio, and only five of the seven banks respect the transformation ratio. ${ }^{6}$ At end-June 2002 , the liquidity ratio was respected by only five of the seven banks, compared with six banks at the end of 2001.

\section{Structural Reforms and Governance}

14. With the assistance of the World Bank, there was further progress in structural reforms. In the cotton sector, preparations are ongoing for the sale of the ginning plants in the two zones that will be opened to private investors in 2003 . One government-owned hotel was sold, and the final preparations are being made for the sale of the telecommunications company, ONATEL. The High Authority for the Fight Against Corruption created in December 2001, is becoming operational. Concerning the improvement in public finance management that is covered by the World Bank's PRSC II, the authorities in July 2002 adopted an action plan consolidating the recommendations of the Budget Management Improvement Plan (PRGB), the Report on the Observance of Standards and Codes (ROSC), and the Country Financial Accountability Assessment (CFAA). The end-June 2002 structural

\footnotetext{
${ }^{5}$ The issue was significantly oversubscribed, testifying to the excess liquidity in the WAEMU. A new issue was placed at maturity, for about twice the original amount issued.

${ }^{6}$ The portfolio structure ratio aims at strengthening the quality of a bank's portfolio by specifying that a minimum of 60 percent of total portfolio will consist of loans rated by the Central Bank of West African States (BCEAO) (and, hence, eligible for BCEAO refinancing operations). The transformation ratio requires that medium- and long-term assets be funded with medium- and long-term liabilities.
} 
performance criterion on the appointment of magistrates to the Supreme Audit Court was met. However, the performance criterion on the elimination of the 59 tariff lines still subject to administratively set customs values was not observed, as the authorities implemented a May 2002 WAEMU directive asking member countries to regularize their position in the WTO by requesting extensions of existing customs valuations. Nonetheless, the Burkinabe authorities reduced the number of tariff lines from 59 to 33 and lowered the reference values on 29 of the remaining 33 commodities by an average of about 20 percent. Also, they will strictly adhere to the decisions of the WTO related to the extension request, namely to: (i) eliminate the customs valuations for which an extension has not been granted; and (ii) phase out the valuations for which an extension has been granted at the end of the extension period. The temporary retention of the remaining administratively set customs valuations is expected to have only a minor impact on Burkina Faso's balance of payments and trade restrictiveness. A recapitulation of structural reforms during the program period is provided in Box 2.

\section{Box 2. Burkina Faso: Structural Reforms Under the PRGF-Supported program}

Throughout the three years of the PRGF-supported program, most of the structural reforms were observed in the time frame specified, however, some were subject to certain delays. In the public finance area, the program set out to improve revenue levels, reform tariffs, and improve the composition and tracking of expenditure. Measures to improve the tax administration were taken early in the program, and public finance management is being improved with the suppott of the World Bank's PRSC. The privatization program involved the sale or liquidation of 41 enterprises and a new list of about 20 enterprises to be sold has been issued. The restructuring of the electricity sector required a longer time frame than originally planned for, as the regulatory framework first needed to be developed with the assistance of the World Bank. The liberalization of the telecommunications sector also proved more time intensive than originally called for. Both are now adequately covered in specific World Bank-supported programs. Good progress was made in the area of petroleum price liberalization, judicial reform and governance. Reforms in the cotton sector transferred to the private sector some of the responsibilities that the parastatal SOFITEX had exercised exclusively before. The cost structure of the cotton sector is now one of the most competitive in the world. Also, two zones will be opened for private investors.

\section{Policy Discussions}

\section{Despite the expiration of the program, the government is determined to strive} for the macroeconomic objectives set for the remainder of the year and the medium term, namely, to consolidate fiscal policies and maintain a fiscal position consistent with the peg of the CFA franc with the euro, and contain the current account deficit. To offset the acceleration of expenditure during the first half of the year, it is essential to reach the projected level of revenues through December 2002, and to control the composition and the level of expenditure in order to preserve social outlays. The government is strongly committed to reducing poverty further by implementing the strategies defined in the PRSP and addressing remaining weaknesses that have constrained the process so far, as laid out in the second annual progress report of the PRSP. 


\section{A. Growth and Inflation}

16. For 2002, the real GDP growth projection bas been revised downward slightly to 5.6 percent, compared with the 5.7 percent projected under the medium-term program. This revision reflects a more conservative forecast for the cotton barvest, which will nonetheless reach a record level. Last year's bumper cotton crop benefited ginning activity and led to solid growth of 7.6 percent in secondary sector real production. This performance, together with increased investment in construction and public works, will lead to an increase of 5.9 percent of real growth in the tertiary sector, concentrated especially in the transportation and trade sectors. Average consumer price inflation is projected at 2 percent because of a continued implementation of prudent monetary policy at the regional level, moderate import prices, and increased food supplies.

\section{B. Fiscal Policy}

17. The primary fiscal objective for the remainder of 2002 is to achieve the programmed level of overall domestic financing of the deficit. The authorities are confident that the measures taken to improve customs revenue and the additional efforts to increase tax collection and combat tax evasion will allow the targeted revenue level to be achieved by year's end. ${ }^{\prime}$ Expenditures for wages and salaries and investment outlays remain in line with the programmed level. To make up for the expenditure overruns in the first half and to counterbalance a higher than initially programmed level of subsidies for cooking oil, butane gas, and fuel delivery for electricity production - a response to the higher-thanexpected level of international oil prices forecast through December $2002^{8}$ - the authorities have identified expenditure cuts in nonessential goods, services, and transfers to bring the fiscal program back on track. The overall deficit (commitment basis, including grants) is projected to be somewhat higher than originally programmed, or 6.4 percent of the revised GDP versus the 5.9 percent of GDP initially projected. Nonetheless, because of a somewhat higher level of net foreign financing, domestic financing will remain as programmed.

\footnotetext{
${ }^{7}$ The nominal amount of tax revenue remains unchanged from the 2002 program projections, but its share of GDP declines from 13.8 percent to 12.9 percent because of the upward revision in the GDP series.

${ }^{8}$ Burkina Faso has an automatic price adjustment mechanism for petroleum products in line with international prices, except for three products. The subsidy on the price of cooking oil and butane gas is well targeted towards the poor and limits deforestation. It is intended to gradually phase out the subsidy on fuel deliveries for electricity production, which essentially benefits upper income groups, as part of the energy sector reform monitored by the World Bank.
} 


\section{Money and Credit}

18. Monetary policy, conducted by the Central Bank of West African States (BCEAO) at the regional level, will continue to focus on improving the external position of the monetary union and maintaining an inflation rate compatible with the peg of the CFA franc to the euro. In line with these objectives, gross official reserves are projected to rise by CFAF 16 billion in 2002, bringing their stock to a level equivalent to 4.5 months of imports of goods and nonfactor services (Table 7). With a further decline in credit to the government, credit to the economy is expected to grow by 12 percent, leaving enough room to support private sector activity, including crop credits. At a rate of about 8.2 percent, broad money expansion is expected to remain in line with nominal GDP growth. In September 2002, the WAEMU Council of Ministers decided that the outstanding stocks of statutory advances to the BCEAO would be amortized over ten years in quarterly installments, starting in 2003 . The fiscal deficit financing will henceforth solely rely on the issuance of securities on the regional market. Given the success of the first two issues, the authorities intend to gradually extend the maturity profile. The overall health of the banking system is likely to remain satisfactory. As a result of a slow-down in cotton exports, the reimbursement of crop credits took place at a slower pace than in previous years. Nonetheless, the cotton company SOFITEX was able to reimburse all 2000-01 crop credits by mid-2002 when the underlying export contracts were executed. Also, nonperforming loans should continue to decline progressively, and are expected to represent 2.2 percent of total credit to the economy by the end of 2002 , compared with a level of 2.5 percent one year earlier.

\section{External Sector}

19. In 2002, higher inflows of official capital are expected to offset the projected deterioration in the trade balance. While exports are projected to grow by 10 percent because of the larger cotton crop, imports, and in particular capital goods imports, are expected to rise by approximately 8 percent, causing the overall trade balance to decline by 7 percent. This robust export growth is forecast to outperform GDP growth, so that the current account deficit (exclucing grants) should narrow to 14.5 percent of GDP in 2002 , compared with a level of 15.1 percent in 2001. Including grants, the current account deficit is targeted at 11.5 percent of GDP. Concerning debt relief, creditors ${ }^{9}$ participation to date represents $\mathbf{7 4 . 2}$ percent of total debt in the topping-up assistance granted at the completion point under the enhanced HIPC Initiative." The Burkinabè authorities are

\footnotetext{
${ }^{9}$ While the IMF, World Bank, African Development Bank, European Union, Arab Bank for Economic Development in Africa (BADEA), and the Paris Club have formally endorsed their full participation in the topping up of assistance provided at the completion point under the enhanced-HIPC Initiative (see Table 8), Paris Club creditors have not yet determined the modalities of delivery for this additional assistance. This will be discussed again at a Paris
} 
actively seeking the participation of non-Paris Club bilateral and multilateral creditors to raise this proportion.

\section{E. Structural Reforms}

20. The remaining reform agenda, undertaken with the World Bank acting as lead agency, includes, in particular, continued reforms in the cotton sector, the privatization program and the restructuring of the energy and telecommunications sectors. In the area of public finance, reforms to strengthen budget execution and procurement, as well as audit procedures, are foreseen. Legal and judicial reforms will be pursued, and the government will adopt measures to strengthen the institutional framework to combat fraud, with the recently established anticorruption authority playing a major role in this respect.

\section{F. Medium-term framework}

21. The discussions were cast in a medium-term context, in line with the PRSP. With the pursuit of flexible policies, efforts to diversify the economy and improve competitiveness, continued fiscal consolidation, implementation of structural reforms, pursuit of good governance, and fighting poverty, the medium-term prospects for the Burkinabe economy remain favorable. Barring further exogenous shocks, real GDP growth is still projected at slightly below 6 percent per annum over the medium-term. However, the economy remains fragile and extremely vulnerable to external shocks. In particular, if the present disturbances in Côte d'Ivoire, with which Burkina Faso has close economic linkages, are not resolved quickly, the Burkinabè economy could be significantly affected. ${ }^{10}$

22. It was agreed that fiscal consolidation is paramount. It is not intended to introduce major changes in the fiscal legislation in the 2003 Finance Law, but to concentrate efforts on widening the tax base and improving the fiscal administration, including through the set up of an integrated computerized revenue system. The authorities have requested FAD's technical assistance in this regard. Revenue is projected to increase gradually over the medium term. Increases in expenditure will be contained below nominal GDP growth, while continuing to favor the social sectors. As a result, the overall fiscal deficit is projected to decline gradually from 6.4 percent of GDP in 2002 to below 3 percent of GDP in 2005, allowing for a progressive reduction in domestic debt.

Club meeting scheduled for November 2002. Also, one of Burkina Faso's non-Paris Club creditors, Libya, has recently agreed to participate in the HIPC Initiative.

${ }^{10}$ It is still too early to make a full assessment of the events in Côte d'Ivoire on the Burkinabè economy. However, with around 2.5 million Burkinabè nationals living in Côte d'Tvoire, it could possibly face a major inflow. The government has already prepared contingency plans (with four scenarios, namely a return of $125,000,250,000,500,000$, or 1 million nationals). 
23. In the external sector, in light of Burkina Faso's limited degree of trade openness, low level of competitiveness, and lack of diversification (see Box 3), exports are projected to rise only gradually over the medium-term, resulting in only modest improvements in the trade and current balances. New exogenous shocks, in the form of further declines in international cotton prices or an escalation of the events in Côte d'Ivoire, would have a significant negative impact.

\section{G. Poverty Reduction}

24. A progress report on the second year of implementation of the PRSP was prepared in May-June 2002, and discussed with representatives of civil society and donors during a twoday seminar in July. The report presents the results achieved in 2001 and lays out the measures the government is planning to pursue in 2002-03 in order to achieve its poverty reduction objectives.

25. In the joint staff assessment of the PRSP, the staff concludes that weak revenue performance and the late disbursement of donor assistance in 2001, coupled with Burkina Faso's limited absorption capacity (see Box 1), presented obstacles to a smooth implementation of the poverty reduction strategy. While there was a marked acceleration of social expenditure in the first half of 2002, further improvements in budget management and planning are desirable. Regarding education, school enrollment and literacy rates improved in 2001 , albeit by less than originally targeted in the PRSP. In the area of health, progress was made with regard to raising immunization coverage rates, increasing health center staffing, and lowering the prices of drugs and selected services. Yet the demand for curative care remained sluggish. Moreover, the government is working on broadening the set of social performance indicators, as it realized that the former set was subject to factors beyond its control. The government also acknowledged that the role of sectoral groups in monitoring the PRSP implementation needed to be clarified. Finally, the staff recommends that the participatory process be broadened and decentralized. Overall, the government has made laudable progress in the fight against poverty and is committed to addressing remaining weaknesses.

\section{H. Possible Successor Arrangement}

26. The authorities have indicated that they will request a successor PRGF arrangement in early 2003 to consolidate the gains achieved in an uncertain international environment under the present program, and to prepare for graduation from the PRGF framework. A set of options in the fiscal and structural areas that could constitute the core of this new program was discussed with the government and representatives of the Finance and Budget Committee of Parliament, and is presented in Appendix VI. All the Burkinabè representatives insisted that the main aim of the next program should be to devise specific ways to accelerate growth, including by further diversifying of the economy and improving financial intermediation. 


\section{Box 3. Burkina Faso: Recent Trends in Trade Patterns}

In order to create a relatively open customs union, the West African Economic and Monetary Union (WAEMU) implemented a common trade policy on January 1,2000. After a gradual four-year implementation period, all member countries adopted a common external tariff (CET). ${ }^{1}$ For the WAEMU zone, the harmonized trade policy has reduced the unweighted average tariff rate from about 19 percent in 1997 to 12 percent in 2000 , thus shifting the overall trade regime's classifiçation to "relatively open" in the Fund's classification of trade regimes. ${ }^{2}$ Moreover, internal trade within WAEMU essentially enjoys a zero tariff rate.

Burkina Faso is one of the most compliant member countries regarding the respecting of the regional norms of WAEMU and the only member country fully compliant with the implementation of the CET. Nonetheless, its application of the harmonized trade regime is not flawless. After eliminating state trading in cotton, rice, and sugar, Burkina Faso continues to impose a quantity-based import restriction on sugar (in the form of a thousand ton minimum import quantity) and to apply administratively set import values on 33 product lines (see text). ${ }^{3}$

Overall, the dismantling of intemal trade baniers is beginning to have an effect on Burkina Faso's intraregional trade patterns (see Figure 6). Over the last four years, the country increased its trade with WAEMU member countries (as a share of the country's total trade) from 20 percent in 1998 to 24 percent in 2001. Furthermore, Burkina Faso has diversifjed the destination of its exports within WAEMU member countries. In 1998, Côte d'Ivoire used to be Burkina Faso's main export recipient, receiving over 60 percent of its total recorded exports. In 2001, this share fell to 38 percent, while Niger and Mali received larger shares of, respectively, 26 percent and 20 percent of Burkinabè exports to WAEMU. Burkina Faso's imports, however, continuc to originate largely from Côte d'Ivoire, representing over 80 percent of imports from WAEMU in 2001. Overall, these figures suggest that intratrade liberalization has induced WAEMU member countries to reassess their respective comparative advantages and to change their trade pattems accordingly.

With respect to the rest of the world, Burkina Faso has reduced its trade with European countries, while raising it with Asian countries (see Figure 7). During 1998-2001, after reducing both exports to and imports from Europe (by, respectively, 16 percent and 14 percent), Burkina Faso's trade with Europe (as a percentage of the country's total recorded trade) fell by almost 10 percentage points, reaching 47 percent in 2001. Total trade with Asia (as a share of total recorded trade) rose from 14 percent in 1998 to 18 percent in 2001, largely owing to higher exports to Japan and higher imports from China.

Overall, Burkina Faso continues to be a poor, landlocked sub-Saharan country with limited resources and a high vulnerability to external shocks. Although trade represents 30 percent of the country's GDP, the degree of trade openness remains modest, given that 75 percent of this ratio is due to imports. Intraregional trade liberalization seems to have brought trade diversion rather than trade creation. To benefit fully from a more open trade regime, greater export diversification must be promoted. In 2001, cotton, which is Burkina Fasa's main traditional export product, accounted for over 5 percent of GDP and almost 60 percent of the country's total exports. A positive step in this direction was the government's organization of an investors' forum last year, which seems to have brought a new impetus to foreign direct investment (FDI) in Burkina Faso. By the end of 2002, 18 private FDI projects are cxpected to take place in Burkina Faso, including with Canadian, French, and British private companies.

1. For details, refer to African Department, West African Economic and Monetary Union: Recent Economic Development and Regional Policy Issues in 2000, IMF Country Report No. 1/193 (Washington: IMF, 2001).

2. African Department, West African Economic and Monetary Union: Recent Economic Development and Regional Policy Issues in 2000, IMF Country Report No. 1/193, (Washington: IMF, 2001), p. 26.

${ }^{3}$ Senegal also imposes a quantity-based restriction on sugar jmports, and Senegal and Côte d'Ivoire also apply administratively set import values. 


\section{STAff APPRaisal}

27. Burkina Faso continued to implement its three-year PRGF-supported program in a generally satisfactory manner. The prudent management of the cotton sector in the face of low international prices resulted in a record crop in 2001 and a significant increase in farmers' incomes, without the need for subsidies to support the sector. The ensuing multiplier effects allowed for a higher growth rate, in line with the country's poverty reduction objectives. The outlook for the 2002-03 cotton crops remains favorable. Also, the relentless pursuit of its poverty reduction objectives is starting to show results through an improvement in social outcomes. The authorities should persevere with such flexible policies, while making special efforts to further diversifying the economy and improving competitiveness.

28. For the first time in two years, the authorities were able to reverse the decline in tax revenue in 2001 . However, this was mainly due to the good performance of taxes on international trade, as the outcome in domestic direct and indirect taxation was less than satisfactory. These developments indicate the need to sustain the implementation of fiscal reform, in particular to broaden the tax base and to improve the fiscal administration. The staff welcomes the authorities' recent request for technical assistance from the Fund in this area.

29. The expenditure overrun in the first half of 2002 is regrettable, although part of it was explained by exogenous factors and the election-related outlays. To reverse these slippages, the authorities have identified expenditure cuts in nonessential goods, services, and transfers for the second half of the year. The staff considers that the effect of this slippage is minor overall and remains confident that the proposed measures will be implemented and the fiscal program brought back on track. Nonethcless, the overrun confirms the need to pursue fiscal consolidation with steadfast determination this year and in the medium term by continuing to increase revenues and to limit nonessential outlays, so as to generatc savings that can be redirected toward the domestically funded investment program and the social sectots.

30. The monetary policy conducted on the regional level remains adequate for Burkina Faso. However, significant efforts are needed to improve financial intermediation and access to credit, without which growth will remain below potential. Also, diversification policies should be pursued relentlessly to građually reducc Burkina Faso's vulnerability to external shocks.

\section{The authorities should be commended for continuing to pursue the poverty} reduction objectives embedded in their PRSP, for having increased the budgetary outlays in the social areas, and for significantly accelerating the commitment of HIPC Initiative resources to make up for the slow start during the past two years. These efforts should be pursued, in particular by addressing remaining absorption bottlenecks, continuing to broaden the participatory process, and improving the tracking of social outcomes. 
32. The structural reform program remains adequate and attuned to Burkina Faso's needs. The nomination of the magistrates to the Supreme Audit Court will allow it to become operative and fulfill its essential role in certifying the government's final accounts. The structural performance criterion on the elimination of the tariff lines still subject to administratively set customs values was not observed. While this slippage has only a limited effect on the external accounts and on the overall trade policy, the staff encourages the Burkinabè authorities to rapidly eliminate the remaining customs valuations, so as to continue liberalizing the trade regime while improving the competitiveness of the econony.

33. The authorities have indicated that they will request a successor PRGF arrangement in early 2003 . In the meanwhile, they remain determined to achieve the macroeconomic, structural, and poverty reduction objectives agreed upon with the staff. On the basis of the satisfactory performance of the program, as well as the authorities' actions to correct the expenditure overrun in the first half of 2002 and the relatively minor effect of the slippage on the elimimation of the administratively set customs valuations, the staff recommends that the requested waivers be granted and the sixth review under the three-year PRGF arrangement be completed. 
Figure 1. Burkina Faso: Real and Nominal Effective Exchange Rates, January 1990- July 2002 (Index, 1990=100)

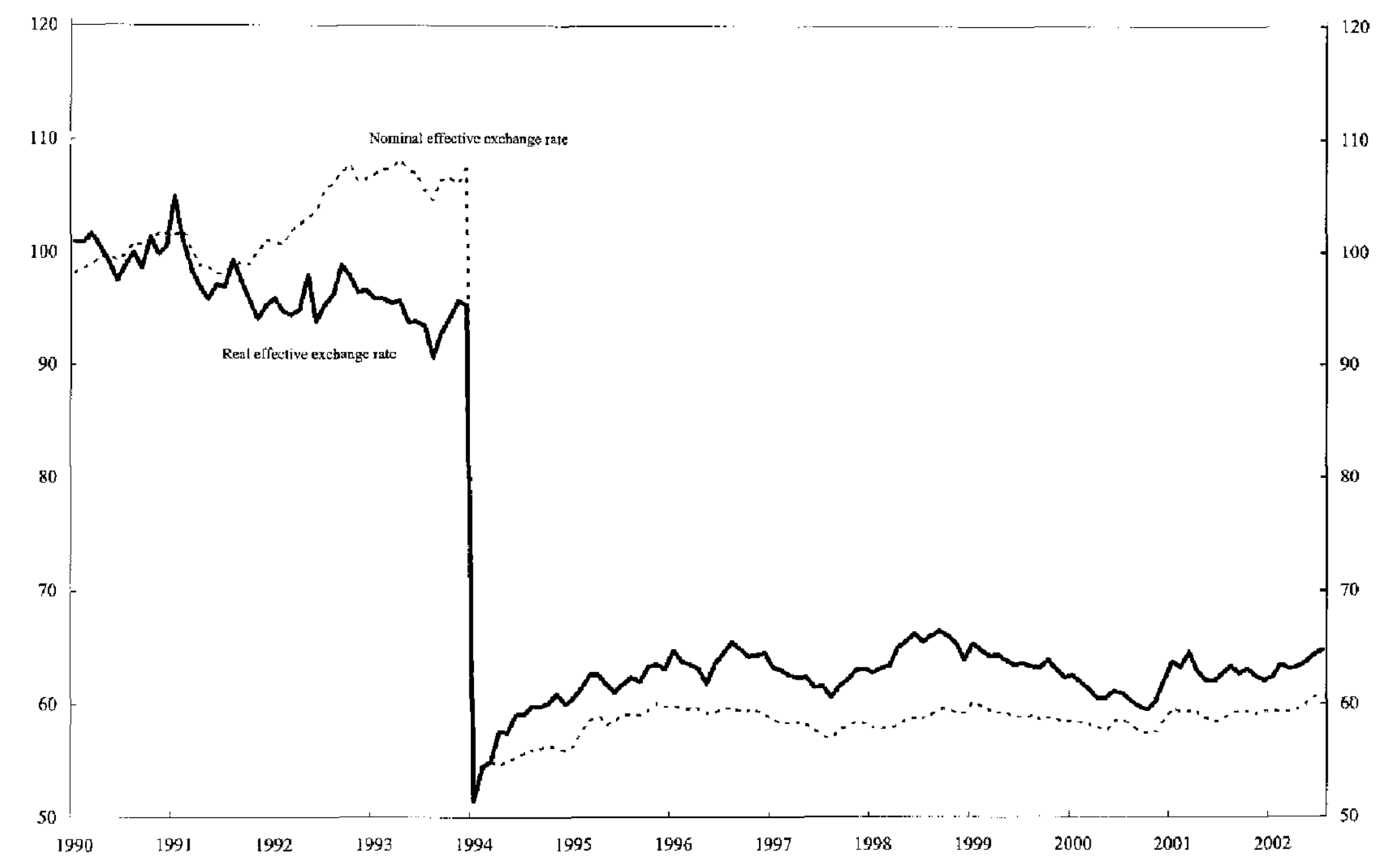

Source: IMF, Information Notice System. 
Figure 2. Burkina Faso: Investment and Savings, 1993-2003

(In percent of GDP)
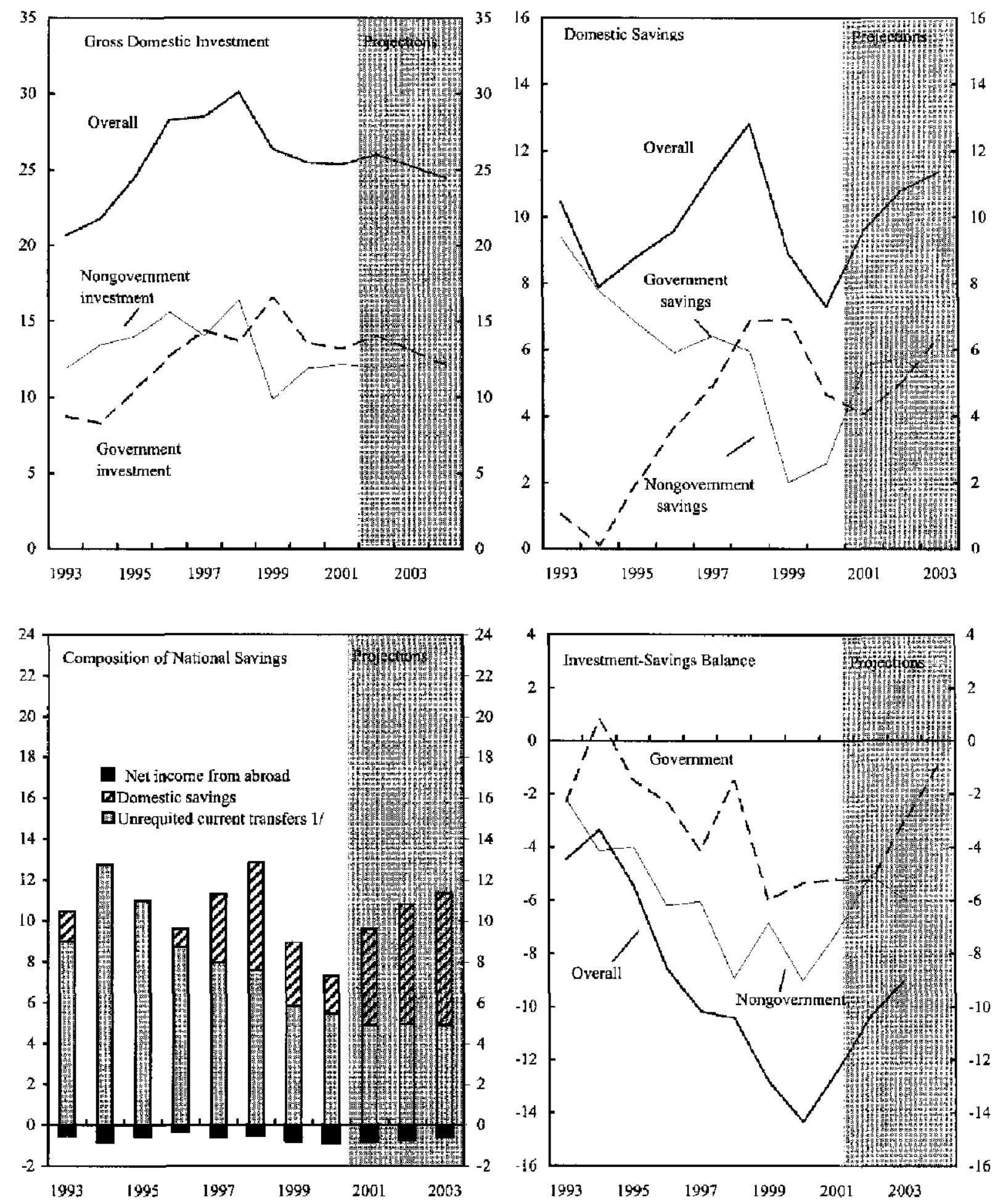

Sources: Burkinabè authorities; and staff estimates and projections.

1/ Budgetary grants, technical assistance, worker remittances, and other transfers, including from nongovernmental organizations. 
Figure 3. Burkina Faso: External Sector Developments, 1993-2003
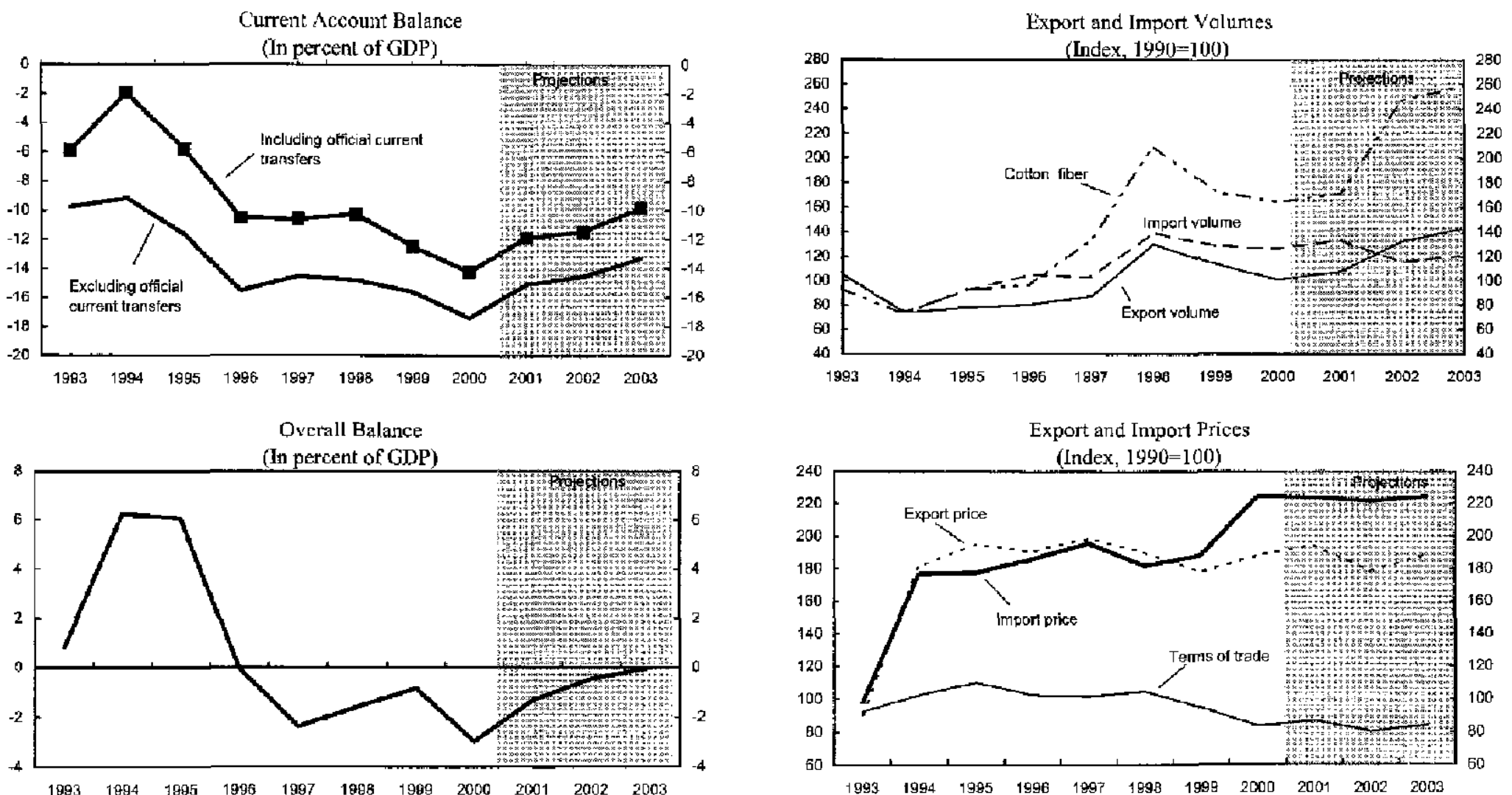

Sources: Burkinabè authorities; and staff estimates and projections. 
Figure 4. Burkina Faso: Fiscal Sector Developments, 1994-2003

(In percent of GDP)

\section{Government Revenue and Expenditure}

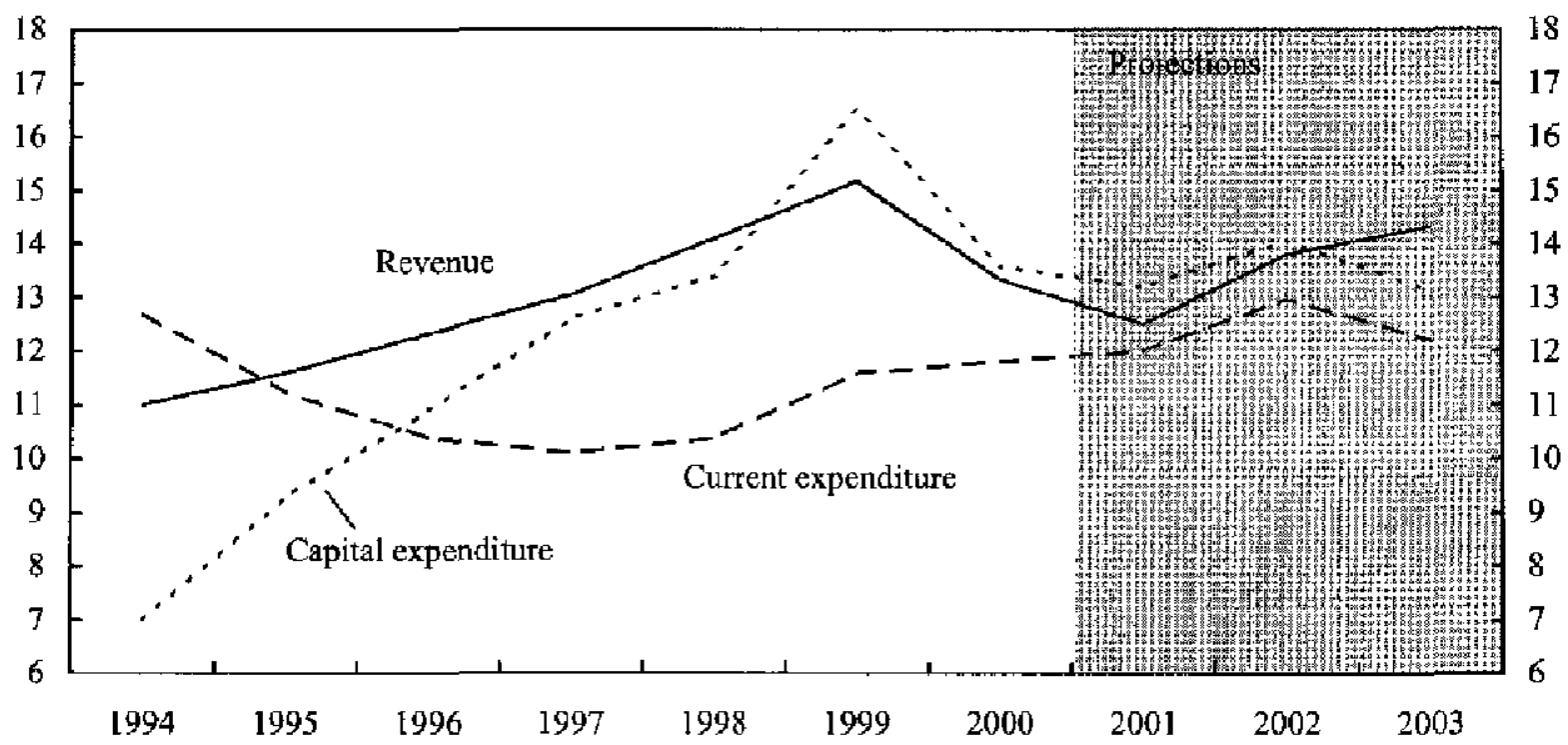

Fiscal Balances

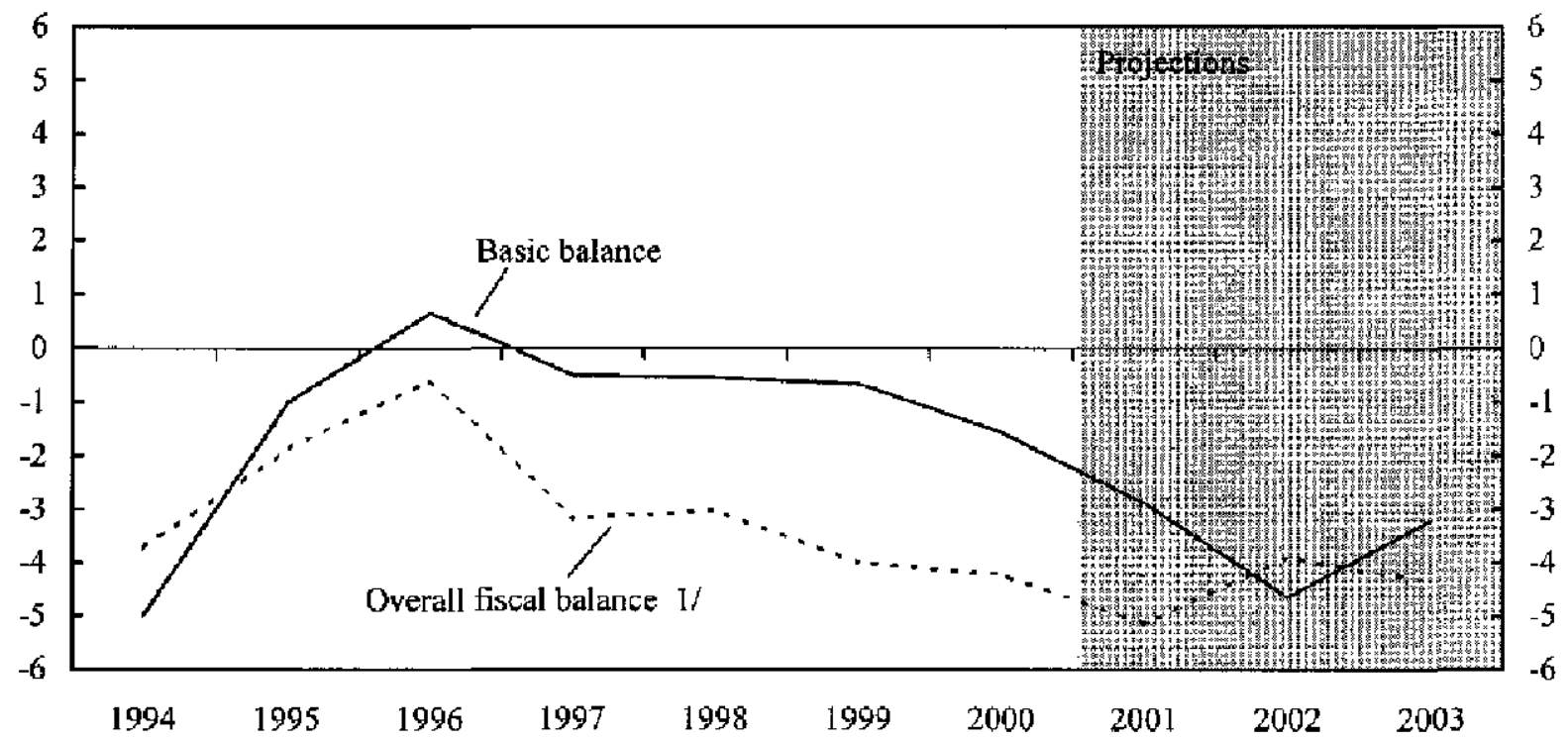

Sources: Burkinabè authorities; and staff estimates and projections.

1/ Commitment basis, including grants. 
Figure 5. Burkina Faso: HIPC Initiative Expenditures Committed, 2001-03
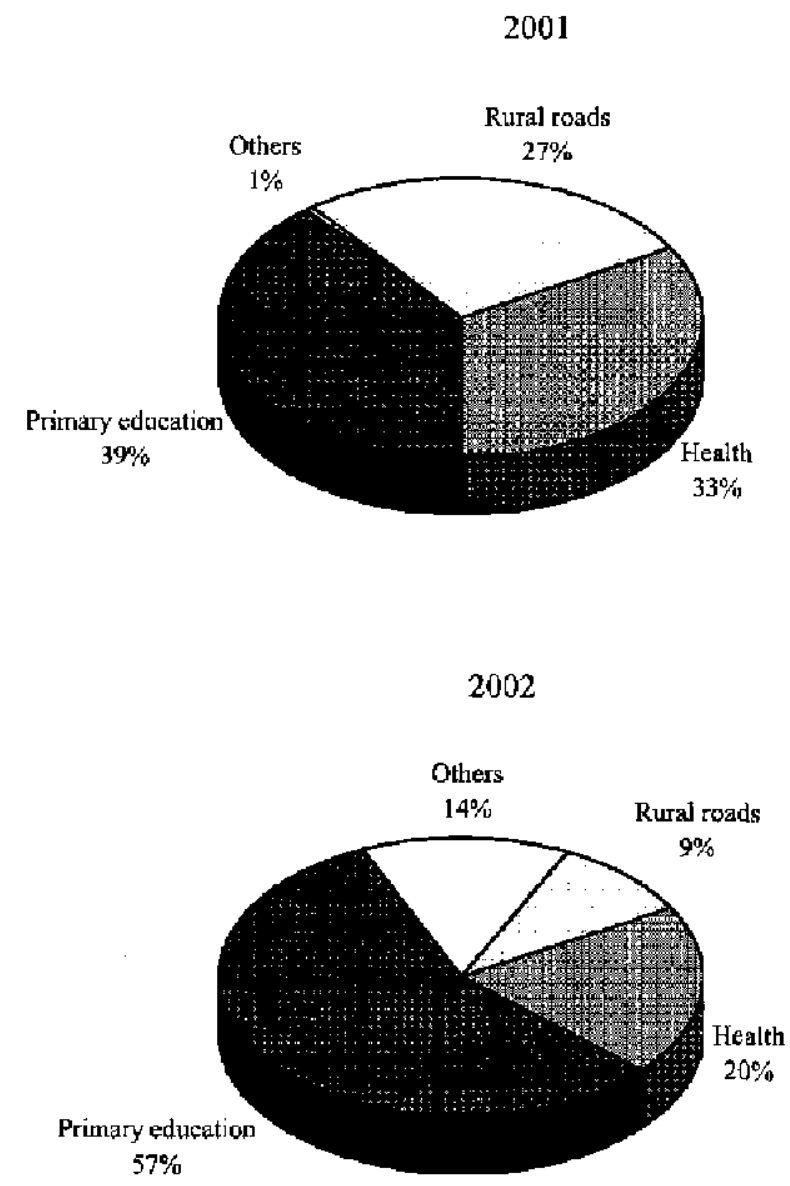

2003

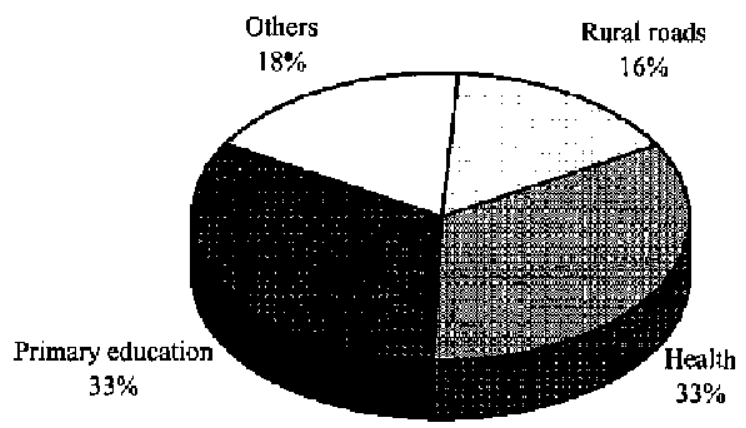

Source: Burkinabè authorities. 
Figure 6. Burkina Faso: Direction of Trade with WAEMU, 1998 and 2001

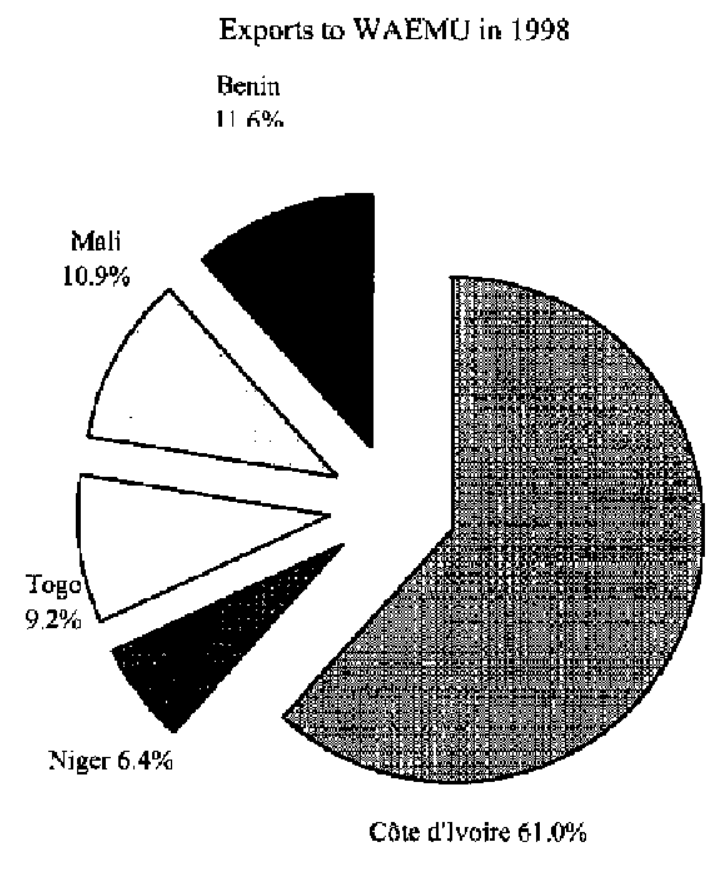

Imports from WAEMU in 1998

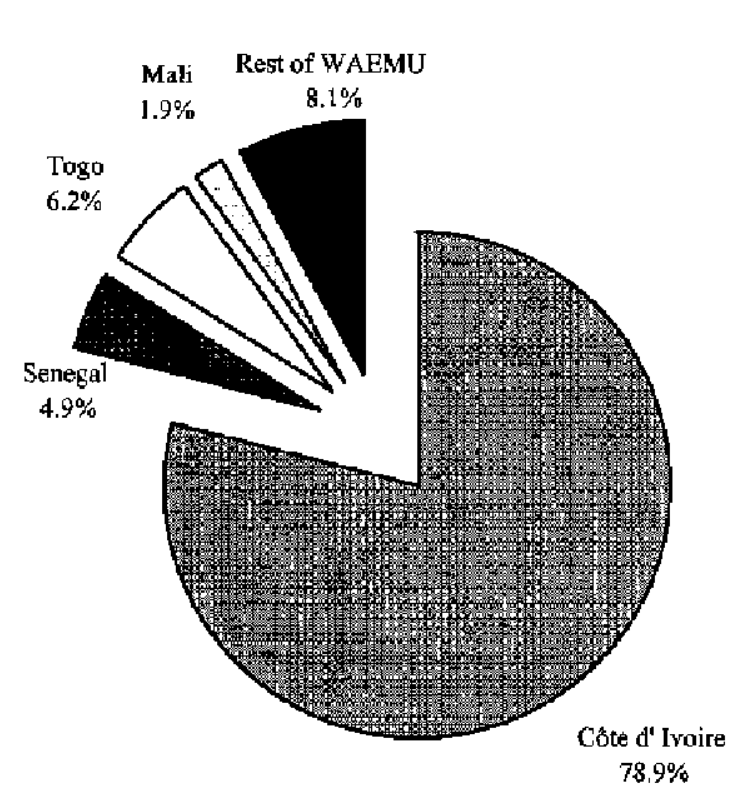

Exports to WAEMU in 2001

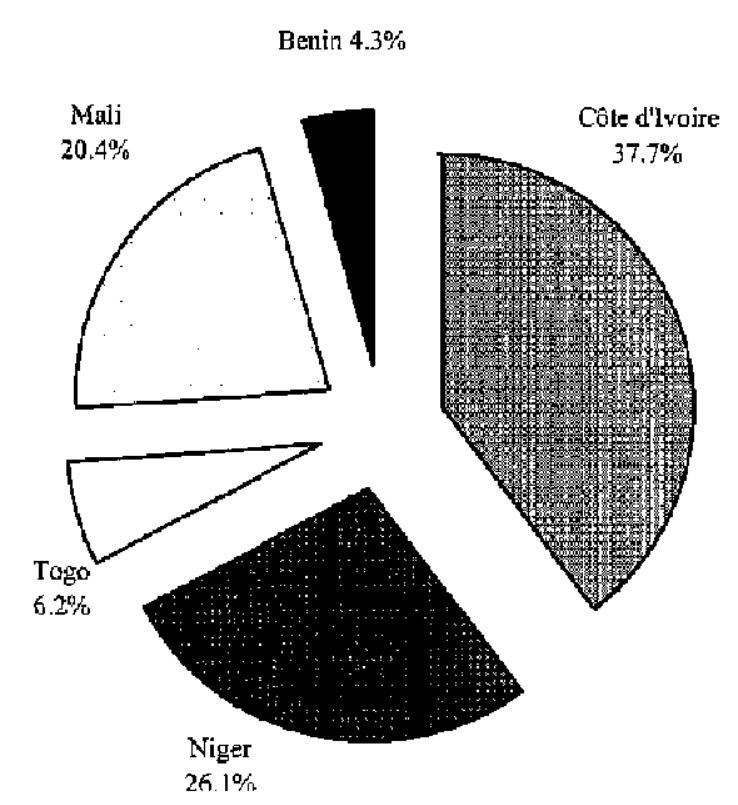

lmports from WAEMU in 2001

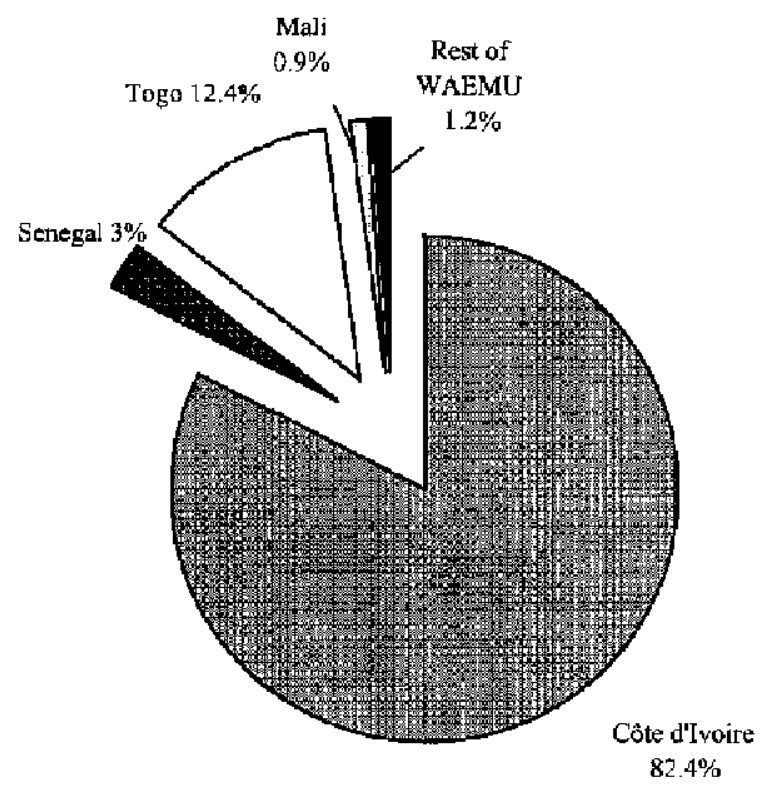

Sources: Central Bank of West African States (BCEAO), and National Institute of Statistics and Demographics (INSD). 
Figure 7. Burkina Faso: Direction of Trade with World, 1998 and 2001

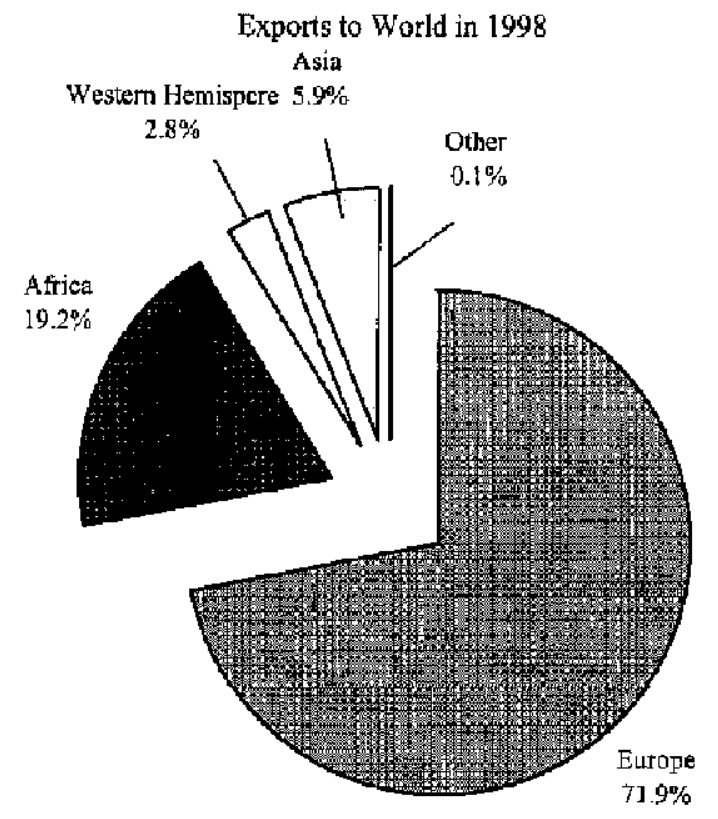

Imports from World in 1998

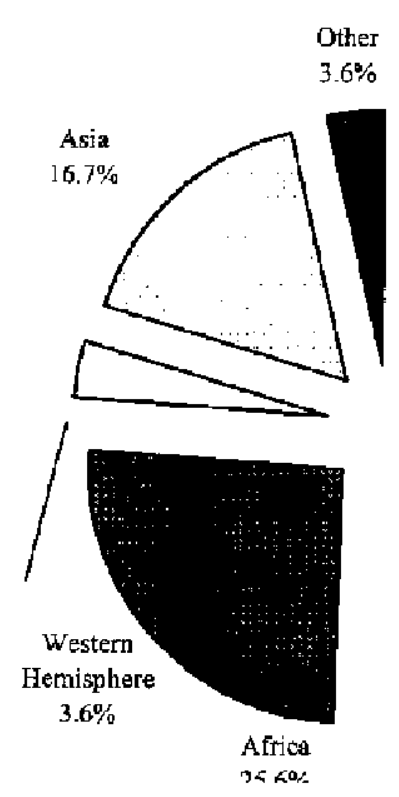

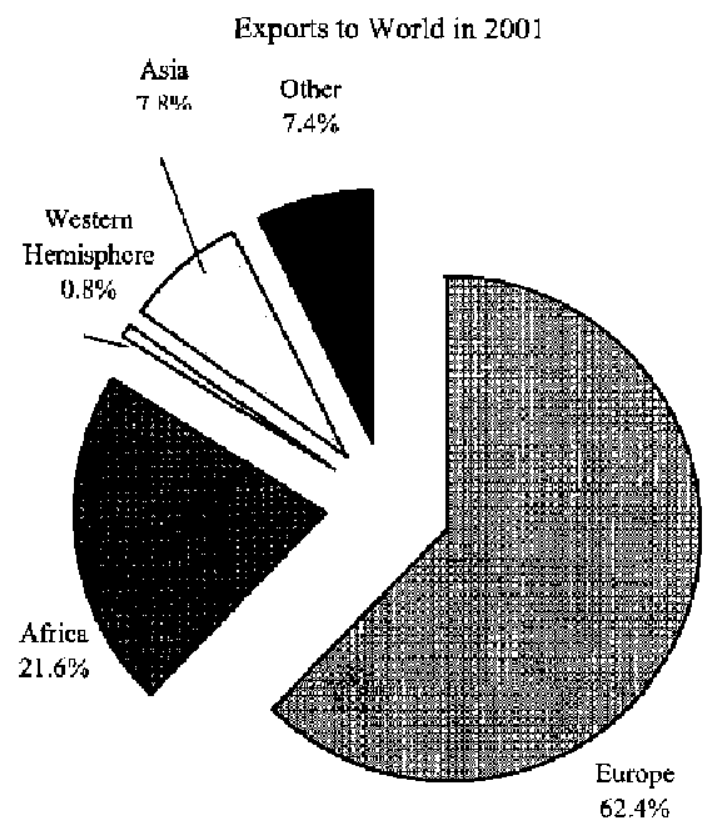

Imports from World in 2001

$$
\begin{aligned}
& \text { Asia } \\
& 2.1 \%
\end{aligned}
$$

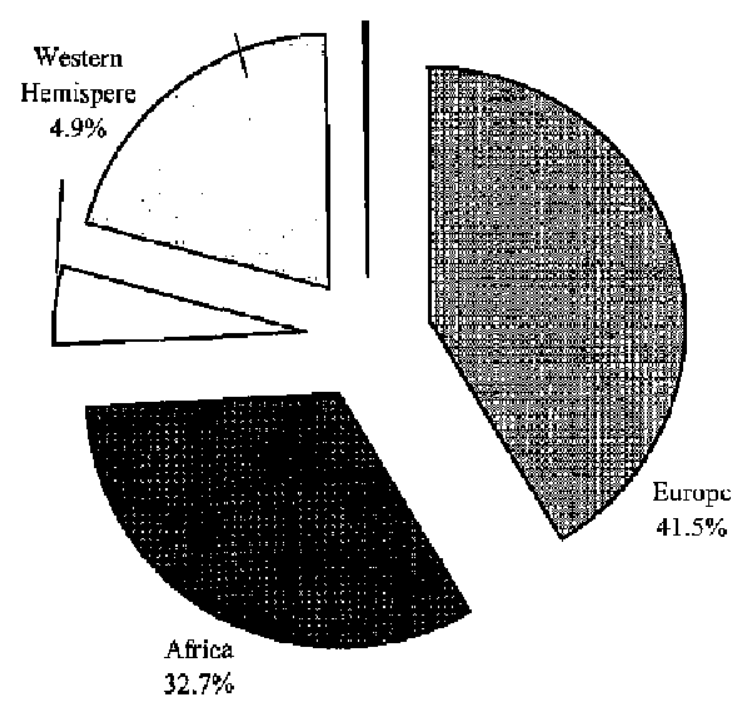

Sources: Central Bank of West African States (BCEAO), and National Institute of Statistics and Demographics (INSD). 
Table 1. Burkina Faso: Fund Position, 2001-10

\begin{tabular}{|c|c|c|c|c|c|c|c|c|c|c|}
\hline & 2001 & 2002 & 2003 & 2004 & 2005 & 2006 & 2007 & 2008 & 2009 & 2010 \\
\hline & \multicolumn{10}{|c|}{ (In millions of SDRs) } \\
\hline IMF, net & 5.9 & 0.3 & -13.2 & -14.1 & -12.2 & -10.5 & -12.5 & -11.4 & -8.8 & -6.9 \\
\hline IMF purchases, disbursements $(+)$ & 16.8 & 11.2 & 0.0 & 0.0 & 0.0 & 0.0 & 0.0 & 0.0 & 0.0 & 0.0 \\
\hline IMF repurchases, repayments (-) & -10.1 & -10.2 & -12.6 & -13.5 & -11.7 & -10.1 & -12.1 & -11.1 & -8.5 & .6 .7 \\
\hline IMF charges and interests (-) & -0.8 & -0.7 & -0.6 & -0.6 & -0.5 & -0.4 & -0.4 & -0.3 & -0.3 & -0.2 \\
\hline Outstanding Fund credit & 92.7 & 93.7 & 81.1 & 67.6 & 55.9 & 45.8 & 33.7 & 22.6 & 14.1 & 7.4 \\
\hline Quota & 60.2 & 60.2 & 60.2 & 60.2 & 60.2 & 60.2 & 60.2 & 60.2 & 60.2 & 60.2 \\
\hline \multicolumn{11}{|l|}{ Exchange rate (period average) } \\
\hline \multirow[t]{2}{*}{ CFA francs per SDR } & 932.3 & 902.8 & 887.0 & 885.4 & 885.4 & 885.4 & 885.4 & 885.4 & 885.4 & 885.4 \\
\hline & \multicolumn{10}{|c|}{ (In billions of CFA francs) } \\
\hline $\mathrm{IMF}$, net & 5.5 & 0.3 & -12.3 & -13.2 & -11.5 & -7.4 & -8.2 & -7.0 & -4.7 & -3.1 \\
\hline IMF purchases, disbursements ( + ) & 15.6 & 10.1 & 0.0 & 0.0 & 0.0 & 0.0 & 0.0 & 0.0 & 0.0 & 0.0 \\
\hline IMF repurchases, repayments (-) & -9.4 & -9.2 & -11.8 & -12.6 & -11.0 & -7.0 & -7.8 & -6.7 & -4.4 & -2.9 \\
\hline IMF charges $(-)$ & -0.7 & -0.6 & -0.5 & -0.5 & -0.5 & -0.4 & -0.4 & -0.3 & -0.3 & -0.2 \\
\hline Outstanding Fund credit & 86.5 & 84,6 & 72.0 & 59.9 & 49.5 & 40.6 & 29.9 & 20.0 & 12.5 & 6.6 \\
\hline Quota & 56.1 & 54.3 & 53.4 & 53.3 & 53.3 & 53.3 & 53.3 & 53.3 & 53.3 & 53.3 \\
\hline
\end{tabular}

Source: IMF, Treasurer's Department. 
Table 2. Burkina Fasu: Selectad Econonic and Financial Lndicators, 2000-05

\begin{tabular}{|c|c|c|c|c|c|c|c|}
\hline & \multirow[t]{2}{*}{2000} & 2001 & \multicolumn{2}{|c|}{2002} & 2003 & 2004 & 2005 \\
\hline & & \multicolumn{3}{|c|}{ Est. Rev. Prog. Rev. Proj. } & \multicolumn{2}{|c|}{ Proj. } & \\
\hline & \multicolumn{7}{|c|}{ (Annual percentage changes, unless olaerwise specified) } \\
\hline \multicolumn{8}{|l|}{ aDP and prices } \\
\hline GDP at constant prices & 2.2 & 5.6 & 5.7 & 5.6 & 5.7 & 5.8 & 5.8 \\
\hline GDP dellaw & 3.2 & 4.8 & 1.7 & 2.9 & 3.2 & 2.6 & 2.6 \\
\hline Consumer prices index (annual average) & -0.3 & 4.9 & 2.0 & 2.0 & 20 & 2.0 & 2.0 \\
\hline Consumes prices (end of period) & 2,4 & 1.0 & 2.0 & 2.0 & 20 & 2.0 & 2.0 \\
\hline \multicolumn{8}{|l|}{ Money and credit } \\
\hline Nel doutestic assets (banking system) It & 15.4 & 2.7 & 1,4 & 4,3 & 73 & 7.2 & 6.4 \\
\hline Credil to the government $1 /$ & 7.8 & -5.2 & -1.4 & -2.7 & -4.3 & -2.8 & -3.2 \\
\hline Credit to the private sector $\mathrm{l} /$ & 8,2 & 7.4 & 2.8 & 7.1 & 11.6 & 10.0 & 9.6 \\
\hline Brond money (M2) & 5.7 & 3.3 & 10.6 & 8,2 & 13.4 & 7.7 & 8.4 \\
\hline Velocity (GDP/M2) & 4.0 & 4.3 & 3.8 & 4.3 & 4.1 & 4.2 & 4.2 \\
\hline \multicolumn{8}{|l|}{ External soctor } \\
\hline Exports (f.o.b; walued in CFA francs) & -6.4 & 10.5 & 8.1 & 9.9 & 15.0 & 11.2 & 10.0 \\
\hline Imports (f.o.b.: valued in (FA francs) & 3.1 & 1.3 & 1.7 & 8.0 & 6.4 & 4.3 & 4.9 \\
\hline Volume of exporis & -11.4 & 1.5 & 17.7 & 19.6 & 10.1 & 6.7 & 0.0 \\
\hline Valume or imports & -13.7 & 1.6 & 2.7 & 14.4 & 8.4 & 5.2 & 4.8 \\
\hline Terms of trade & 10.5 & -4.8 & -7.2 & 6.5 & -0.4 & -2.0 & -0.4 \\
\hline Real eftective exchange rate (depreciation -) & -4.6 & 3.3 & $\ldots$ & $\ldots$ & $\ldots$ & $\ldots$ & $\ldots$ \\
\hline ' & \multicolumn{7}{|c|}{ (In percent of GDP, unless otherwise specified) } \\
\hline Oross investment & 25.5 & 25.4 & 28.1 & 26.0 & 253 & 24.5 & 24.5 \\
\hline Govermment & 13.6 & 13.2 & 15.2 & 14.1 & 13.I & 12.1 & 11.6 \\
\hline Nongovernment sector & 11.9 & 12.2 & 12.9 & 12.0 & L2.1 & 12.4 & 12.8 \\
\hline Grogs domestic serjings & 3.3 & 9.6 & 13.4 & 10.8 & $1], 4$ & 11.6 & 12.4 \\
\hline Govemment savings & 4.7 & 4.1 & 7.0 & 5.1 & 6.4 & 7.5 & 8.1 \\
\hline Nongovernment savings & 2.6 & $\$ .5$ & 6.4 & 5.7 & 5.0 & 4.1 & 4.3 \\
\hline Gross national sayings & 18.5 & $2 u .1$ & 17.8 & 20.2 & 20.1 & 19.7 & 19.7 \\
\hline \multicolumn{8}{|l|}{ Central government finances } \\
\hline Ter revenue & 12,3 & 11.7 & 13.8 & 12.9 & 13.3 & 13.6 & 14.0 \\
\hline Curren1 expenditure & 11,8 & 12.0 & 13.4 & 13.0 & 12.2 & 11.6 & 11.7 \\
\hline Operall fiscal balanete, excluding grants & -12.3 & -12.6 & -13.5 & -13.1 & -10.9 & -9.1 & -8.2 \\
\hline Overall fiscal balanee, includicug grants & -4.1 & -4.5 & -5.9 & -6.4 & -4.3 & -2.9 & -2.8 \\
\hline Basic bafance $2 /$ & $-1,6$ & .2 .9 & -4.3 & -4.6 & -3.2 & $-2,4$ & -2.3 \\
\hline Exçhding use of HIPC Initiative tesources & -1.1 & -2.6 & -2.9 & $-3,4$ & -1.9 & .0 .9 & -1.0 \\
\hline \multicolumn{8}{|l|}{ Externai sector } \\
\hline Exports of goods and nonfactor services & 10.2 & 10.1 & 11.2 & 10.2 & 10.6 & 10.8 & 10.9 \\
\hline Imports of goods and nonfactor services & 28.4 & 25.9 & 26.0 & 25,4 & 24.5 & 23.7 & 22.9 \\
\hline Curant account balance (excludits current official isansfers) & -16.9 & -15.1 & -14.1 & -94.5 & -13.3 & -12.3 & -11.4 \\
\hline Curtent account balance (including curtent oflicial transfers) & -13.8 & -11.9 & -10.5 & -11.5 & -9.8 & -8.8 & -8.3 \\
\hline \multicolumn{8}{|l|}{ Extemal debt indieators (before НГРC Initiative) } \\
\hline Debt-scrvice ratio $3 f$ if & 30.2 & 22.5 & 25.8 & 22.7 & 20.9 & 19.6 & 17.9 \\
\hline Gtoks official reserves (in months of imports of gouds and nonfactor services) & 4.4 & 4.4 & 5.3 & 4.5 & 49 & 4.8 & 4.7 \\
\hline Nominal GDP (in billions of CFA franes) & 1,646 & 1,822 & 1,834 & 1.979 & 2,158 & 2,342 & 2,542 \\
\hline
\end{tabular}

Sowces: Burkinabè authorities; and skef estimatę and prọjections.

1/ In percent of beginsing-of-period broad inoney.

2f Revenze, exululing grants, minus expenditures, oxcluding foreign-financed investment ouclays.

From 1998 on, reverue includes takes paid by contractors on foreign-financed pualic investments using checks issued by the treasury.

3! In percent of exports of goods and nonfactor sęricess.

4f After traditional debt-rclief mechanisme and including original Heavily lndebted Poor Countries Jnitiative (HIPC) assistance delivered as uf end-2001. 
Table 3 Burkiria Faru: Consolidated Operaticans of the Central Oovernment, $200 \mathrm{~L}$-0s

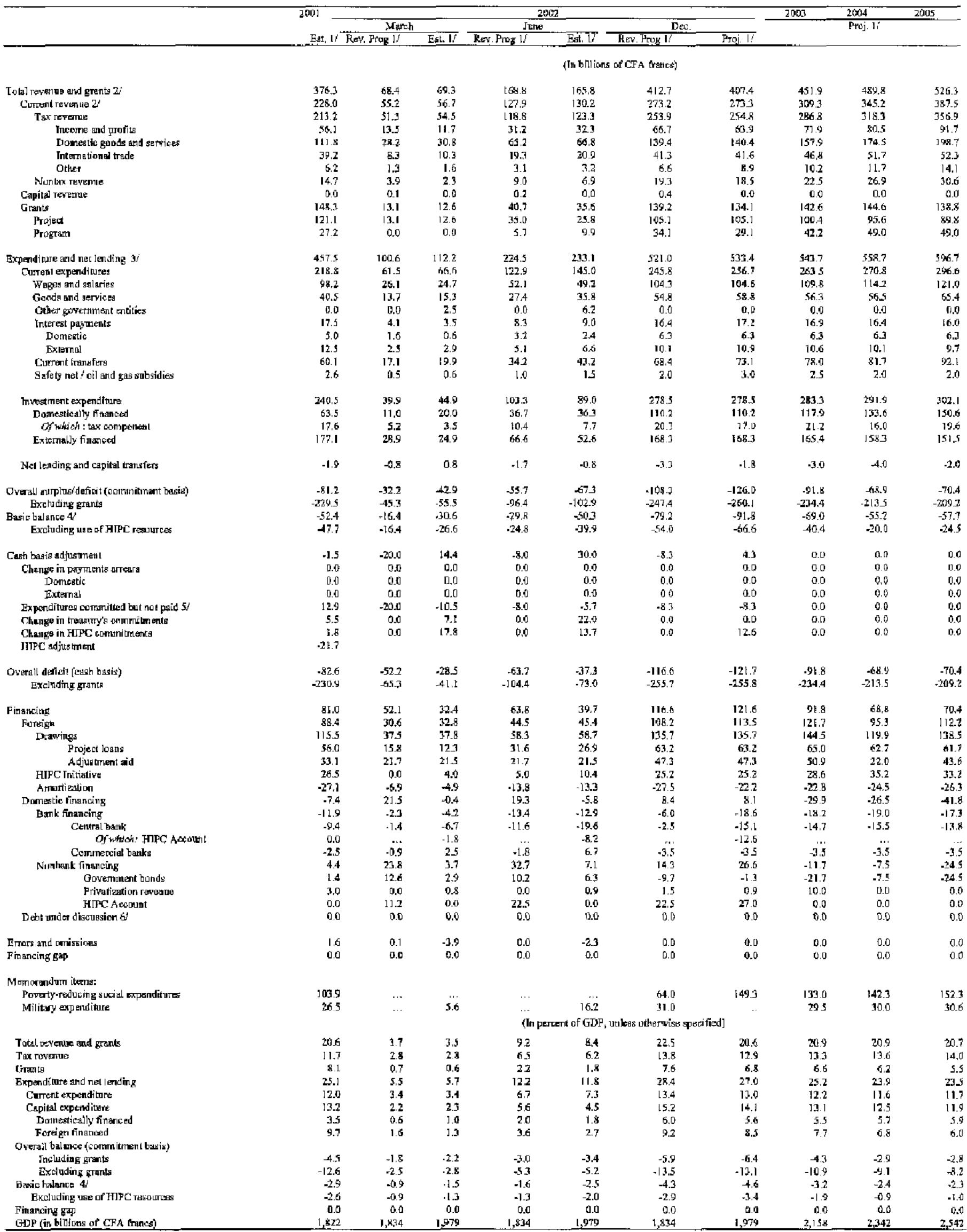

Sources: Burkimabe authorities; and s18ff estimates and projections,

1/ Inoluda HIPC rasources.

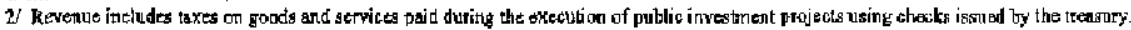

3/ On a commitment basis and includith the tax component of the publis investment projects, which is peid by the (reasury.

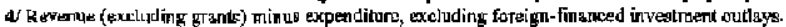

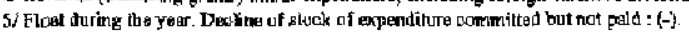

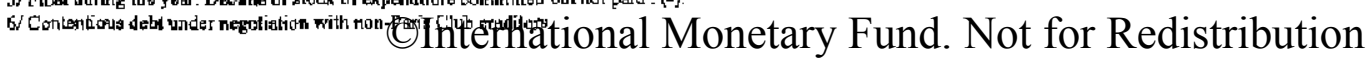


Table 4. Burkina Faso: Fiscal Imp3ct of the HIPC Initiative, 2000-015

(In billions of CFA francs, unless otherwise specificd)

\begin{tabular}{|c|c|c|c|c|c|c|}
\hline & \multirow[t]{2}{*}{2000} & \multirow[t]{2}{*}{2001} & 2002 & 2003 & 2004 & 2005 \\
\hline & & & \multicolumn{4}{|c|}{ Proj. } \\
\hline \multicolumn{7}{|c|}{ Initiative for Hcavily Indebted Poor Countries (HIPC Initiativc) assistance given } \\
\hline A. Interest due before HIPC Initiative assistance & 13.1 & 12.5 & 10.9 & 10,6 & 10.1 & 9.7 \\
\hline B. Intcrost paid before HIPC Initiative assistance & 13.1 & 12.5 & 10.9 & 10.6 & 10.1 & 9.7 \\
\hline \multicolumn{7}{|l|}{ C. HIPC Initiative assistance on interest } \\
\hline (as a rcsult of stock-of-debt operation otly) & 0.0 & 0.0 & 0.0 & 0.0 & 0.0 & 0.0 \\
\hline D. Interest due after HIPC Initiative assistance & 13.1 & 12.5 & 10.9 & 10.6 & 10.1 & 9.7 \\
\hline E. Amortization dhe before HIPC Initiative assistance & 27.8 & 27.1 & 22.2 & 22.8 & 24.5 & 26.3 \\
\hline F. Amorization paid before HIPC Initiative assistance & 27.8 & 27.1 & 22.2 & 22.8 & 24.5 & 26.3 \\
\hline \multicolumn{7}{|l|}{ G. HIPC Initiative assistance on amortization } \\
\hline (as a result of stock-of-debt operation only) & 0.0 & 0,0 & 0.0 & 0.0 & 0,0 & 0.0 \\
\hline 11. Amortization due after HIPC Initiative assistance & 27.8 & 27.1 & 22.2 & 22.8 & 24.5 & 26.3 \\
\hline \multicolumn{7}{|l|}{ 1. HIPC Initiative assistance provided as grants } \\
\hline (to cover debt service due) & 0.0 & 0.0 & 0.0 & 0.0 & 0.0 & 0.0 \\
\hline \multicolumn{7}{|l|}{ I. HIPC Initiative assistance as exceptional financing } \\
\hline (to cover debt service due) & 7.1 & 26.5 & 25.2 & 28.6 & 35.2 & 33.2 \\
\hline Total HIPC Initiative assistance $(\mathrm{C}+\mathrm{G}+\mathrm{H}+\mathrm{J})$ & 7.1 & 26.5 & 25.2 & 28.6 & 35.2 & 33.2 \\
\hline Total HIPC Initiative assistante (in millions of U.S. dollars) & 100 & 36.2 & 36.1 & 42.7 & 52.7 & 50.0 \\
\hline \multicolumn{7}{|l|}{ Net cash flow to the budget from HIPC Initiative } \\
\hline assistancc $(\mathrm{B}+\mathrm{F}-(\mathrm{D}+\mathrm{H}-\mathrm{I}-\mathrm{T}))$ & 7.1 & 26.5 & 25.2 & 28.6 & 35.2 & 33.2 \\
\hline \multicolumn{7}{|l|}{ Memorandum ttems: } \\
\hline Other doner flows & 201.3 & 237.3 & 244.7 & 28.7 .1 & 264.5 & 277.3 \\
\hline \multicolumn{7}{|l|}{ Total net oxternal flows } \\
\hline (net extemal financing less dcbi service due) & 160.4 & 197.7 & 211.5 & 25.3 .7 & 229.8 & 241.3 \\
\hline \multicolumn{7}{|l|}{ Povarty reduction government expenditures' } \\
\hline Baseline pre-HIPC Initiative assistance expenditure projections & 85.9 & 97.3 & 97.1 & $\ldots$ & $\ldots$ & \\
\hline Post-HIPC Initiative assistanee cxpenditurc projections & 85.9 & 103.9 & 149.3 & 133.0 & 142.3 & 152.3 \\
\hline \multicolumn{7}{|l|}{ Memorandum items: } \\
\hline Tax revenue (in percent of GDP) & 12.3 & 11.7 & 12.8 & 13.3 & 13.5 & 14.0 \\
\hline \multicolumn{7}{|l|}{ Overall fiscal balance before H[PC Initiative assistance } \\
\hline \multicolumn{7}{|l|}{ Overall fiscal balance after HIPC Initiative assistance } \\
\hline (in percent of GDP) & -4.1 & -4.5 & -6.4 & -4.3 & -3.0 & -2.8 \\
\hline
\end{tabular}

Sources: Burkinabè authoritics; and staff projections.

'Excludes foreign-financed investment. 
Table 5. Burkinu Fasc: Poverty-Reducing Social Expenditures, 1996-2002

(Ineluding use of HIPC Initiative Ressurces)

\begin{tabular}{|c|c|c|c|c|c|c|c|}
\hline & 1996 & 1997 & 1998 & 1949 & 2000 & 2001 & 2002 \\
\hline & & & Actual & & & Est. & Proj. \\
\hline & & & (As a percet & c of tolal ex & ditarre) & & \\
\hline Total poverty-reducing social expendituro & 20.7 & 19.8 & 19.4 & 18.3 & 20.4 & 22.7 & 28.0 \\
\hline Curreat & 11.5 & 10.8 & 10.2 & 10.4 & 12.0 & 12.4 & 14.0 \\
\hline Capital & 9.2 & 9.0 & 9.1 & 7.9 & 8.4 & 10.4 & 14.0 \\
\hline Health & 10.8 & 9.5 & 9.0 & 8.7 & 7.9 & 9.5 & 9.9 \\
\hline Current cxpendilure & 4.6 & 4.7 & 4.6 & 4.3 & 4.7 & 5.2 & 6.3 \\
\hline Capital expenditurc & 6.3 & 4.9 & 4.5 & 4.4 & 3.2 & 4.3 & 3.6 \\
\hline Domestic resourees & 0.4 & 0.5 & 1.8 & 1.0 & 0.8 & 1.1 & 1.8 \\
\hline Externul expenditure & 5.9 & 4.4 & 3.5 & 3.4 & 2.5 & 3.3 & 1.8 \\
\hline Education & 8.6 & 9.5 & 9.3 & 8.7 & 10.6 & 11.0 & 13.3 \\
\hline Current expendituno & 6.2 & 5.6 & 5.0 & 5.4 & 6.5 & 6.4 & 5.9 \\
\hline Capital expenditute & 24 & 3.9 & 4.3 & 3.3 & 4.1 & 4.6 & 7.3 \\
\hline Donestic resources & 0.5 & 0.5 & 0.7 & 0.7 & 0.6 & 13 & 3.5 \\
\hline External expendiuse & 1.9 & 3.4 & 3.6 & 2.6 & 3.5 & 3.4 & 3.8 \\
\hline Women's uelfare and other poverty-reducing sacial expenditure & 1.3 & 0.8 & 1.0 & 0.9 & 1.2 & 1.2 & 3.4 \\
\hline Current expenditure & 0.7 & 0.6 & 0.6 & 0.7 & 0.8 & 0.7 & t.8 \\
\hline Capital expenditurc & 0.6 & 0.2 & 0.4 & 0.1 & 0.4 & 0.4 & 1.6 \\
\hline Domestic resources & 0.2 & 0.1 & 0.1 & 0.1 & 0.1 & 0.1 & 0.1 \\
\hline External expenditure & 0.4 & 0.1 & 0.3 & 0.1 & 0.4 & 0.4 & i.5 \\
\hline Rural toads (capital) & 0.0 & 0.0 & 0.0 & $\theta .0$ & 0.7 & 1.1 & $\$, 4$ \\
\hline Domestic restourees & 0.0 & 0.0 & 0.0 & 0.0 & 0.0 & 0.4 & 0.8 \\
\hline External funds & 0.0 & 0.0 & 0.0 & 00 & 0.7 & 0.7 & 0.6 \\
\hline & & & As a & centage of $\mathrm{G}$ & & & \\
\hline Total poverty-reducitg social expethditure & 4.6 & 4.8 & 4.7 & 5.1 & 5.2 & 5.7 & 7.5 \\
\hline Cument & 2.5 & 2.6 & 2.5 & 2.9 & 3.1 & 3.1 & 3.8 \\
\hline Capilal & 2.0 & 2.2 & 2.2 & 2.2 & 2.2 & 2.6 & 3.8 \\
\hline Healith & 2.4 & 2.3 & 2.2 & 2,4 & 2.0 & 2.4 & 2.7 \\
\hline Curreat expenditure & 1,0 & I.] & 1.1 & 1.2 & 1.2 & 1.3 & $\mathrm{l} .7$ \\
\hline Capital expenditure & 1.4 & 1.2 & 1.1 & 1.2 & 0.8 & 1.1 & $b_{0} 0$ \\
\hline Dornestic resources & 0.1 & 0.1 & 0.2 & 0.3 & 0.2 & 0.3 & 0.5 \\
\hline External expenditure & 1.3 & 1.1 & 0.8 & 1.0 & 0.6 & 0.8 & 0.5 \\
\hline Education & 1.9 & 2.3 & 2.3 & 2.4 & 2.7 & 2.8 & 3.6 \\
\hline Cument expenditure & 1.4 & 1.4 & 1.2 & 1.5 & 1.7 & 1.6 & 1.6 \\
\hline Capital expendjare & 0.5 & 1,0 & 1.0 & 0.9 & 1.0 & 1.1 & 2.0 \\
\hline Domente rescurces & 0.1 & 0.1 & 0.2 & 0.2 & 0.1 & 0.3 & 1,0 \\
\hline External expenditurc & 0.4 & 0.8 & 0.9 & 0.7 & 0.9 & 0.8 & 1.0 \\
\hline Women's welfare and other poverty-redu cing social expenditure & 03 & 0.2 & 0.2 & 0.2 & 0.3 & 0.3 & 0.9 \\
\hline Сursent expenditure & 0.2 & 0.1 & 0.1 & 0.2 & 0.2 & 0.2 & 0.5 \\
\hline Capital expenditure & 0.1 & 0.0 & 0.1 & 0.0 & 0.1 & 0.1 & 0.4 \\
\hline Domestic resources & 0.0 & 0.0 & 0.0 & 0.0 & 0.0 & 0.0 & 0.0 \\
\hline Extcrnal expenditure & 0.1 & 0.0 & 0.1 & 0.0 & 0.1 & 0.1 & 0.1 \\
\hline Rural roada (efapital) & 0.0 & 0.0 & 0.0 & 0.0 & 0.2 & 0.3 & 0.4 \\
\hline Domestic nesouroes & 0.0 & 0.0 & 0.0 & 0.0 & 0.0 & 0.1 & 0.2 \\
\hline External tunds & 0.0 & 0.0 & 0.0 & 0.0 & 0.2 & 0.2 & 0.2 \\
\hline
\end{tabular}

Sources: Ministry of Economy and Finance; and staff estimates and projections. 
Table 6. Burkina Faso: Monetary Survey, $1999-2002$

\begin{tabular}{|c|c|c|c|c|c|c|c|c|c|c|c|c|c|c|c|}
\hline & \multirow[t]{3}{*}{$1999 \mathrm{U}$} & \multirow[t]{3}{*}{$20001 /$} & \multicolumn{5}{|c|}{2001} & \multicolumn{8}{|c|}{2002} \\
\hline & & & \multirow[t]{2}{*}{ March $\mathbf{v}$} & \multirow[t]{2}{*}{ Ine $1 \gamma$} & \multirow[t]{2}{*}{ Sep.li } & \multicolumn{2}{|c|}{ Dec. } & \multicolumn{2}{|c|}{ Marchs } & \multicolumn{2}{|c|}{ June } & \multicolumn{2}{|c|}{ Sen. } & \multicolumn{2}{|c|}{ Dew. } \\
\hline & & & & & & Pmg. $1 /$ & Est & Prag. $\mathrm{b} /$ & Es.. & Prog. I/ & Est & Prog, $\mathrm{l}^{\prime}$ & Prooj, & Prog. $1 /$ & Froj. \\
\hline & \multicolumn{15}{|c|}{ (In thithons of CFA fremes) } \\
\hline Net foreign assets & 163.5 & 125.5 & 128.2 & 125.4 & 109.2 & 130.9 & [28.1 & 141.0 & 151.8 & 141.5 & 139.1 & 151.5 & 143.1 & 170.9 & 144.3 \\
\hline Central Bank of Wert African States (BCEAO) $2 /$ & 91.6 & 54.J & 60.4 & 679 & 47.2 & 30.3 & 76.5 & $\%, 4$ & 79.4 & 89.8 & 72.4 & 99.9 & 76.5 & 119.3 & 92.7 \\
\hline Absetsis & 192.2 & 171.3 & 173.8 & 178.7 & 160.3 & 198.1 & 194.0 & 200.2 & 195.8 & 208.7 & 190.0 & 218.8 & 194.0 & 238.5 & 210.1 \\
\hline Liabilities & -100.5 & -117.2 & -113.4 & .110 .9 & -113.I & -118.8 & -117.5 & $-1 L .8$ & -116.4 & -118.8 & -117.6 & -118.8 & -117.6 & -119.2 & -117.4 \\
\hline Commercial banks 2 & 71.9 & 71.7 & 67.7 & 57.6 & 62.0 & 51.6 & 51.6 & 51.6 & 72.4 & 51.6 & 66.6 & 51.6 & 66.6 & 51.6 & 51.6 \\
\hline Nef dormesslic assets & 225.3 & 285.3 & 301.3 & 291.2 & 311.7 & 300.3 & 296.2 & 3340 & 298.5 & 319.9 & 249.9 & 314.1 & 305.7 & 306.1 & 314.7 \\
\hline Net Oomestic ctratit & 237.0 & 299.3 & 309.7 & 299.4 & 318.1 & 308.8 & $3 \cos , 4$ & 318.2 & 316.9 & 299.7 & 309.3 & 3160 & 324.8 & 299.5 & 326.8 \\
\hline Net credit to governuncret & 49.8 & 80.3 & 79.8 & B0.8 & 85.9 & 59.3 & 58.8 & 57.1 & 54.1 & 46.1 & 49.1 & 58.7 & 84.0 & 53.2 & 47.3 \\
\hline Treasury & 93.9 & 113.7 & 117.4 & 109.6 & 119.7 & 101.4 & 101.9 & 99.2 & 95.8 & 88.2 & 82.3 & 100.8 & 97.3 & 45.3 & 89.3 \\
\hline BCEAO & 60.4 & 83.5 & 89.8 & 83.] & 94,3 & 74.5 & 74.2 & 73.2 & 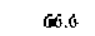 & 63.0 & 53.4 & 76.5 & 51.6 & 71.9 & 65.0 \\
\hline Conmercial banks & 33.6 & 30.2 & 27.6 & 26.4 & 25.4 & 26.9 & 27.3 & 26.0 & 29.1 & 25.1 & 29,0 & 24.3 & 23.7 & 23.4 & 24.2 \\
\hline Other central government & $.44,2$ & .33 .5 &.-37.6 & -28.8 & .33 .8 & -42.1 & -43.1 & -42.1 & -41.6 & -42.1 & -33.2 & -42.1 & -33.2 & -42.1 & -42.0 \\
\hline of whinch: project deposits & -23.3 & 18.6 & -1799 & 17.2 & 22.5 & .25 .6 & -25.2 & -25.6 & -28.4 & -25.6 & -28.0 & -25.6 & -28.0 & -25.6 & -25.2 \\
\hline Coedit to the ceonomy & 187.2 & 219.1 & 229.8 & 218.6 & 232.2 & 249.5 & 249.6 & 261.1 & 262.7 & 253.7 & 200.7 & 257.3 & 260.8 & 246.3 & 279.5 \\
\hline Of whis:h: crop trebit & 16.3 & 28.5 & 40.0 & 35.0 & 24.3 & 38.3 & 38.3 & $\$ 9.0$ & 55.0 & 50.0 & $\$ 5.0$ & 37.0 & 37.0 & 38.3 & 38.3 \\
\hline Other items (net) & .11 .8 & -14.2 & -8.4 & -8.2 & -6.4 & -8.6 & -12.2 & 15.8 & -18.4 & 20.1 & $.19,9$ & -1.9 & -19.1 & 6.7 & -12.2 \\
\hline Broad money & 3888 & 410.8 & 429.5 & 416.5 & 420.9 & 431.2 & 424,4 & 475.0 & 450.3 & 461.3 & 429.0 & 465.7 & 448.8 & 477,0 & 459.0 \\
\hline \multirow[t]{2}{*}{ Of which: curtrency in circulation } & 142.6 & 136.1 & 132.4 & 132.1 & 119.4 & 128.2 & 120.6 & 147.4 & 111.7 & {$[4] .1$} & 89,2 & 133.0 & 117.2 & 142.7 & 125.8 \\
\hline & \multicolumn{15}{|c|}{ 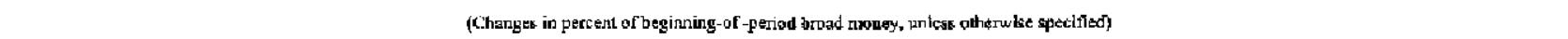 } \\
\hline \multicolumn{16}{|l|}{ Mewerandum itenss: } \\
\hline Nel foreign assets & $-2,4$ & -9.7 & 0.6 & $-0,1$ & -4.0 & 1.2 & 0.6 & 2.3 & 5.6 & 2.5 & 2.6 & 4,8 & 3.5 & 9.3 & 3.8 \\
\hline Net domertic assols & 5.6 & 15.4 & 3.9 & 1.5 & 6.5 & 3.7 & 2.7 & 7.8 & 1.5 & 4.5 & -1.5 & 3.2 & 2.2 & 1.4 & 4.3 \\
\hline Net credit to govermment & 3.4 & 7.8 & -0.1 & 0.1 & 1.4 & -5.1 .1 & -5.2 & -0.5 & -1.1 & $-3,1$ & -2.3 & -0.1 & 1.2 & -3.4 & -2.7 \\
\hline Gedit to the ecomuniny & 1.9 & 8.2 & 2.6 & -0.1 & 3.2 & 7.4 & 7.4 & 2.7 & 3.1 & 1.0 & 2.6 & 1.8 & 2.6 & -0.7 & 7.1 \\
\hline (annuta) percentage chaoge) & 3.9 & 17.0 & 4.9 & -0.2 & 6.0 & 13.9 & 13.9 & 4.7 & 5.3 & 1.7 & $\$ .4$ & 3.1 & 4.5 & -1.3 & 12.0 \\
\hline Money supply & 3.1 & 5.7 & 4.5 & 1.4 & 2.5 & 4.9 & 3.3 & 10.2 & 6.1 & 3.0 & I.J & 8.0 & 5.8 & 10.6 & 8.2 \\
\hline Curtetticy velocilly (GDP/broad money) & 4.0 & 4.0 & $\ldots$ & $\ldots$ & $\ldots$ & 4.2 & 4.3 & $\ldots$ & $\ldots$ & $\ldots$ & $\ldots$ & $\ldots$ & $\ldots$ & 3.8 & 4.3 \\
\hline
\end{tabular}

Rources: Buskivabe authorities; and staff estimatts and projeccenions.

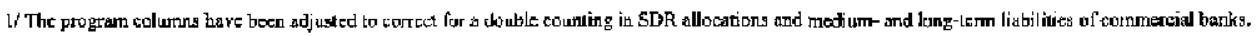

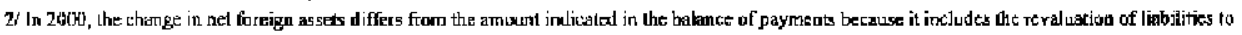

the JMF (CFAF 8.4 billion), which is not taken inta acoount in the balinnce on payments. 


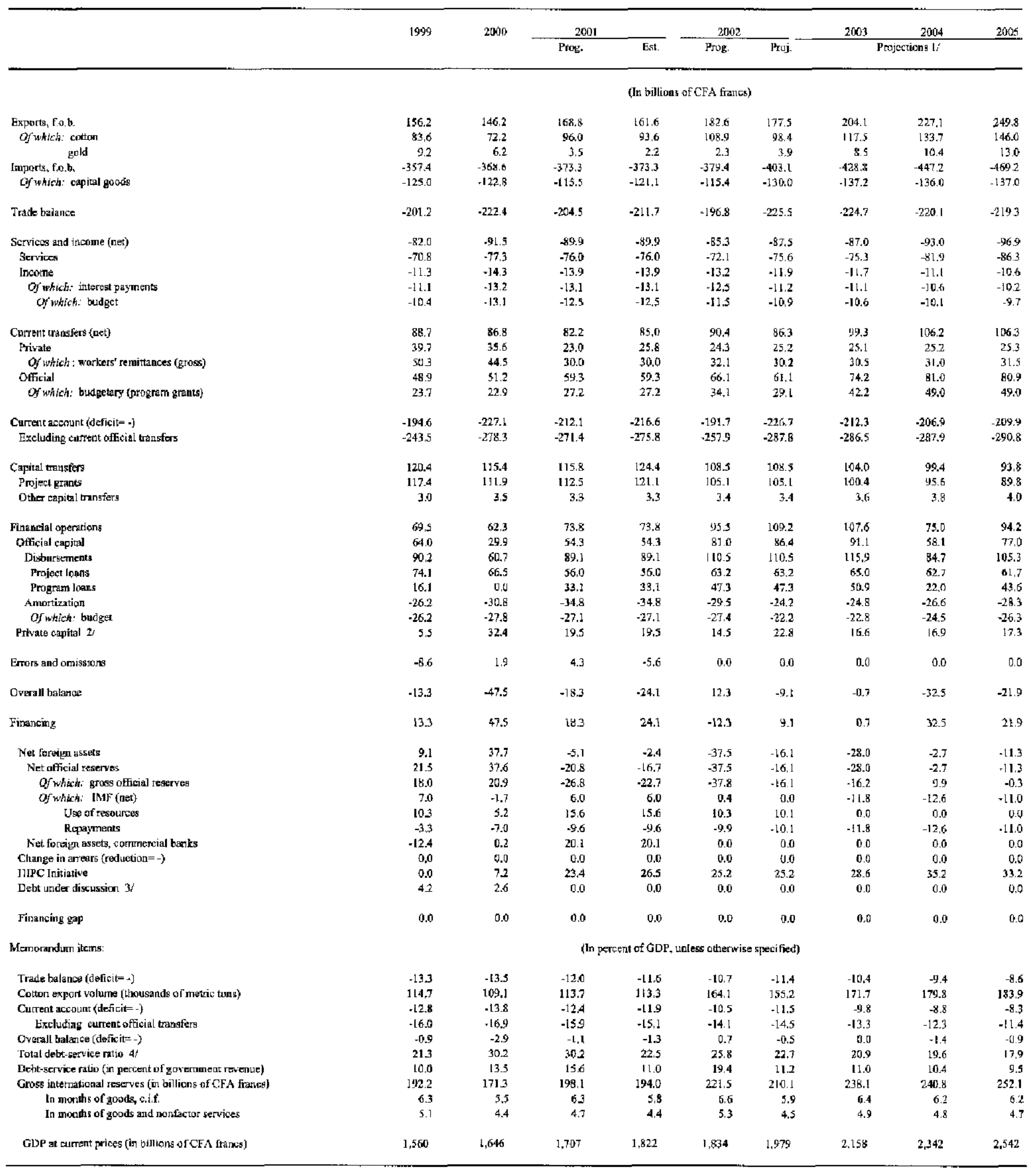

Sources: Cenral Bark of West Africen States (BCEAO); and staff estimates and projections.

I/ Based ont latest Wiond Economic Outbok projections.

2' Includes portfolin irrvestment and foreign direct investrnent.

$\exists /$ Contertions debt in nctotidition with non-Paris Club creditors.

$4 /$ In percent of expotts of goods and wonfactot services. 
Table 8. Burkina Faso: Tracking Delivery of HIPC Initiative Assistance - Original and Enhanced Framework

\begin{tabular}{|c|c|c|c|c|c|c|c|c|}
\hline & \multicolumn{3}{|c|}{ Original } & \multicolumn{5}{|c|}{ Enhanced } \\
\hline & $\begin{array}{l}\text { Agrement to } \\
\text { Provide HIPC } \\
\text { Relief Under Original }\end{array}$ & $\begin{array}{l}\text { Begun to Deliver } \\
\text { Interim } \\
\text { Assistance }\end{array}$ & $\begin{array}{l}\text { Regun to Deliver } \\
\text { Comp. Puinl } \\
\text { Assistance }\end{array}$ & $\begin{array}{l}\text { Agreement to } \\
\text { Provide HIICC } \\
\text { Relief }\end{array}$ & $\begin{array}{l}\text { Agtestient to } \\
\text { Provide [nterim } \\
\text { Assistance }\end{array}$ & $\begin{array}{l}\text { Begun to Deliver } \\
\text { Interim } \\
\text { Assistance }\end{array}$ & $\begin{array}{l}\text { Begun to Deliver } \\
\text { Comp. Point } \\
\text { Assistance }\end{array}$ & $\begin{array}{l}\text { Agrecment to } \\
\text { Provide } \\
\text { Topping Up }\end{array}$ \\
\hline \multicolumn{9}{|l|}{ Multilateral creditors } \\
\hline IMF & yes. & yes & yes & yes & yes & yes & yes & yes \\
\hline IDA & yes & yes & yes & yes & yes & yes & yes & yes \\
\hline African Development Bank/Fund & yes & yes & yes & yes & yes & yes & no & yes \\
\hline International Fund for Agricultural Development & yes & no & yes & yes & yes & yes & no & $\ldots$ \\
\hline European Union & limited & no & $y \Leftrightarrow$ & yes & yes & yes. & no & yey \\
\hline Orgarization of Petroleum Exporting Countries Fund & yes & no & not yet & yes & pending & no & no & $\ldots$ \\
\hline Arub Bank for Econorric Development in Africa & limited & no & $y$ y & yes & pending & no & no & yes \\
\hline Economic Community of West African States & no & $\mathbf{I n j}$ & no & no & no & na & no & $\ldots$ \\
\hline Conseil de l'Fntente & $\mathrm{n} / \mathrm{a}$ & to verify & verify & no & по о & no & по & $\ldots$ \\
\hline West African Development Bark & yes & no & yes & yes & yes & yes & no & $\ldots$ \\
\hline Islamic Development Bank & limited & no & yes & yes & limited & no & no & $\ldots$ \\
\hline \multicolumn{9}{|l|}{ Paris Club creditors } \\
\hline Austria & yes & yes & yes & yes & yes & yes & yes & yes \\
\hline Russia & yes & yes & yes & yes & yes & yes & yes & yes \\
\hline France $1 /$ & yes & yes & yes & yes & yes & yes & yes & yes \\
\hline Italy $1 /$ & yes & yes & yes & yes & yes & yes & yes & yes \\
\hline Netherlands 2 & yes & yes & yes & yes & yes & yes & yes & yes \\
\hline Spain 1 & yes & yes & yes & yes & yes & yes & $y \in s$ & yes \\
\hline Uniled Kingdom & yes & yes & yes & yes & yes & yes & yes & yes \\
\hline \multicolumn{9}{|l|}{ Non-Paris Club bilateral creditars } \\
\hline Algeria & no & no & no & no & no & no & no & $\ldots$ \\
\hline China & no & no & no & no & no & no & no & $\ldots$ \\
\hline Kuwait 3/ & no & no & no & yes & pending & no & ro & $\ldots$ \\
\hline Saudi Arabia & no & no & no & pending & pending & pending & no & $\ldots$ \\
\hline Libya & no & no & no & no & no & no & 110 & $\cdots$ \\
\hline Taiwan Province of Chma & no & no & no & no & no & во & no & $\cdots$ \\
\hline Côte d'IYoire & no & no & no & no & no & no & no & $\cdots$ \\
\hline \multicolumn{9}{|l|}{ Commercial Creditors } \\
\hline Insignificant & not offered & & & not offered & & & & \\
\hline
\end{tabular}

Sources: Burkimabè anthorities; and staff estimates.

1) Bilateral agreements not yet concluded.

2/ The Nethcrlands is ptuviding 100 percent relief, including on its commercial debt.

3/ The Kuwait Furd for Arab Economic Dovelopment is considering providing 100 percent debt relief un pre-cutaff-date ODA loans in line with similar initistives from Paris Club members. 
Table 9. Burkina Faso: Implementation Status of Actions to Strengthen Tracking of Poverty-Reducing Public Spending

\begin{tabular}{|c|c|c|}
\hline Action & Timing & Status $1 /$ \\
\hline \multicolumn{3}{|l|}{ Actions to strengthen budget formulation } \\
\hline Implement the WAEMU budget classification & 2002 & II \\
\hline $\begin{array}{l}\text { Include programming of HIPC funds in 2003-05 mediun-term expenditure } \\
\text { ftamework (MTEF) }\end{array}$ & 2002 & FI \\
\hline Complete information in budget laws using the results of past budget execution & 2002 & NS \\
\hline Make the necessary adjustments to autornatically generate functional budget classification & 2002 & $\mathrm{NS}$ \\
\hline \multicolumn{3}{|l|}{ Actions to strengthen budget execution } \\
\hline Link commitment decisions to cash reserves and reinforce use of cash-flow plan & 2002 & FI \\
\hline \multicolumn{3}{|l|}{ Actions to strengthen budget reporting } \\
\hline Integrate foreign-financed investment spending in computerized expenditure circuit & 2002 & II \\
\hline Take an administrative decision regarding the budget accounts prior to 1994 & 2002 & NS \\
\hline $\begin{array}{l}\text { Regularly produce treasury balanecs and submit budget accounts to the Supreme Audit } \\
\text { Court in time with the budget execution reports }\end{array}$ & 2002 & $\amalg$ \\
\hline Fully operationalize the Supreme Audit Court & 2002 & $\mathrm{II}$ \\
\hline Respect the delays in presenting the budget execution reports to the national assembly & 2002 & II \\
\hline Prepare fiscal accounts on payment order basis & 2002 & I] \\
\hline Intensify and reinforce tracking surveys and disseminate their results & 2002 & [I \\
\hline Systematically follow up on implementation of program budgets and their execution & 2002 & $\Pi$ \\
\hline
\end{tabular}

1/ $\mathbf{F}]=$ fully implemented; $\amalg=$ implementation initiated, $N B=$ not started. 
Ouagadougou, October 18, 2002

Mr. Horst Köhler

Managing Director

International Monetary Fund

Washington, D.C. 20431

Dear Mr. Köhler:

1. On behalf of the government of Burkina Faso, I am pleased to inform you of the progress achieved in the first balf of 2002 in implementing the program supported by the Poverty Reduction and Growth Facility (PRGF) arrangement approved by the Executive Board of the International Monetary Fund on September 10, 1999.

2. In 2002, which has seen multiparty general elections held in May and a subsequent cabinet reshuffle, the economy has performed well, boosted by record cotton production in late 2001; this good performance, in turn, has led to an upturn in consumption, manufacturing, and services. A satisfactory level of tax revenue collection, in particular import duties, and control of expenditures in the first quarter enabled all quantitative benchmarks and indicators to be met as at end-March 2002, except for-because of some expenditure overruns - the indicator on current expenditures.

3. Expenditures related to goods and services and transfers accelerated during the second quarter for essentially two reasons. First, subsidies on fuel deliveries for electricity production and on the price of butane gas and cooking oil were higher than forecast, owing to the rise in world oil and gas prices. Second, expenditures linked to the electoral cycle were higher than expected. Consequently, the indicator on current expenditure and the performance criterion relating to the government's net domestic credit were exceeded as at end-June 2002. The government of Burkina Faso is requesting a waiver for nonobservance of the performance criterion on the government's total net domestic budget financing.

4. The structural performance criterion as at end-June 2002 relating to the appointment of three judges at the Supreme Audit Office was achieved through the appointment in June 2002 of the president of the Supreme Audit Office and the presidents of its three chambers. In contrast, the structural performance criterion relating to the abolition of the 59 tariff lines that are still subject to administratively set customs values was not observed, as described in my letter of June 24, 2002. The West African Economic and Monetary Union (WAEMU) Commission adopted by regulation a list of products eligible to retain their administratively set customs values in the WAEMU member states, and a WAEMU Council of Ministers directive approved on May 23, 2002, proposed that member countries submit a request for extension of existing customs valuations to the World Trade Organization (WTO). Burkina Faso wouId like to benefit temporarily from the opening thus offered by the WAEMU authorities. In any event, at end-May 2002, the government reduced the number of products 
subject to administratively set customs values from 59 to 33 and lowered the reference values for 29 products. The 33 remaining items comprise the group for which a request for extension of customs values has already been submitted to the WTO. The government will comply with the WTO's decisions in this regard, and it will either abolish immediately those reference values for tariff items no longer accepted by the WTO or will abolish them after the grace period allowed by the WTO. The Burkina Faso government requests a waiver for nonobservance of this performance criterion.

5. The government has relentlessly pursued its poverty reduction program, as described in the poverty reduction strategy paper (PSRP). A second PRSP progress report, prepared after a broad-ranging consultation of civil society and development partners, will be sent to you under separate cover. The fiscal resources allocated to the social sectors have continued to increase. In particular, after a fairly slow start in 2001 , the use of resources resulting from debt-service relief under the Heavily Indebted Poor Countries (HIPC) Initiative accelerated sharply in 2002. The entire remainder of the funds from the HIPC Initiative resources of 2001 were committed by mid-September, and the bulk of the funds relating to 2002 resources will be committed before year's end.

6. The outlook for the rest of 2002 remains good. The new cotton crop is promising, despite the fall in world prices. The financial position of the textile fiber company, SOFITEX, remains precarious, but the government is confident that the entity can break even if world prices do not fall further. Despite the expiration of the program, and with a view to establishing a solid basis for a new PRGF-supported program covering 2003-05, the government is determined to meet the end-2002 macroeconomic objectives defined in consultation with the IMF staff. In particular, measures have been taken to sustain the level of tax revenue and restrict the level of expenditure, and the overall budget deficit (on a commitment basis and excluding use of HIPC Initiative resources) will be kept below 4 percent of GDP at end-2002. In addition, some key structural policy options, which could constitute the core of the new program, have already been discussed with Fund staff.

7. The government is counting on the continued support of the International Monetary Fund and is looking forward to the conclusion of the sixth PRGF review. As in the past, the government gives its consent for the publication of the MF staff report.

Sincerely yours,

$/ \mathrm{s} /$

Jean-Baptiste M. P. COMPAORE

Minister of Finance and Budget

Officier de l'Ordre National 
Table 1. Burkina Faso: Quantitative Perfommance Criteria, Benchmarks, and Indicators for the Second- and Third-Year Programs Under the Foverty Rechetion and Growth Facility Arrangement, 2001-02

(In billians of CFA tranes; cumulative from beginning of year)

\begin{tabular}{|c|c|c|c|c|c|c|c|c|}
\hline & 200 & & & & 200 & & & \\
\hline & End-Dec & & End-M & & End- & & End-Segi. & End Des. \\
\hline & $\begin{array}{r}\text { Perfomance } \\
\text { Criteria } \\
\end{array}$ & Actual & Benchmark & Actual & $\begin{array}{r}\text { Performance } \\
\text { Criterin } \\
\end{array}$ & Actual & Proj- & Proj. \\
\hline Perfomsace cuiteria and benchmarls i/ & & & & & & & & \\
\hline Ceiling on cumulative change in net bank credit to govemment & -5.2 & -11.9 & $\ldots$ & & $\ldots$ & & $\ldots$ & \\
\hline Adjusted ceiling for shorffall in extemal resources & 8.7 & & $\ldots$ & & $\ldots$ & & $\ldots$ & \\
\hline Ceiling on tunulative clunge in total net dorrestic hudget financing (both bank and noubank) $y$ & $\ldots$ & & 10.3 & 1.3 & -3.2 & 2.4 & 0.4 & -6.3 \\
\hline Adjusted ceiling for shortfall in extemal assistance & $\ldots$ & $\ldots$ & $\ldots$ & & -7.1 & & & \\
\hline Ceiling on the cumutative amount of new nonsoncessional borrowing & & & & & & & & \\
\hline contracted ar guarantead by the governmetit 3 & 0.0 & 0,0 & 0.0 & 0.0 & 0.0 & 0.0 & 0,0 & 0.0 \\
\hline Of which: less than one year's maturity $3 / 4 t$ & 0.0 & 0.0 & 0.0 & 0.0 & 0.0 & 0.0 & 0.0 & 0.0 \\
\hline Accumulation of domestic payments arrears $3 / 5 t$ & 0.0 & 0.0 & 0.0 & 0.0 & 0.0 & 0.0 & 0.0 & 0.0 \\
\hline Accumulation of extenal payments amears $3 t$ & 0.0 & 0.0 & 0.0 & 0.0 & 0.0 & 0.0 & 0.0 & 0.0 \\
\hline Indicators $\mathbf{1} /$ & & & & & & & & \\
\hline Ourrent government revenue $6 /$ & 231.0 & 210.4 & 50.0 & 53.2 & 117.5 & 122.5 & 186.1 & 256.3 \\
\hline Expenditure on wages and salaries $2 /$ & 98.2 & 97.5 & 26.1 & 24.0 & 52.1 & 48.4 & 78.2 & 102.2 \\
\hline Cirrent expenditure & 219.8 & 218.8 & 61.5 & 66.6 & 122.9 & 145.0 & 184.4 & 256.7 \\
\hline Adjustment factors $1 / 7 /$ & & & & & & & & \\
\hline Balance of payments assistance & 74.2 & 60.3 & 21.7 & 21.5 & 27.4 & 31.3 & 57.2 & 76.4 \\
\hline Adjustrnent londing (excluding IMH) & 54,3 & 33.1 & 21.7 & 21.5 & 21,7 & 21.5 & 47.3 & 47.3 \\
\hline A dinstment grants & 19.9 & 27.2 & 0.0 & 0.0 & 5.7 & 9.9 & 99 & 29.1 \\
\hline Debt relief $8 /$ & 0.0 & 0.0 & 0.0 & 0.0 & 0.0 & 0.0 & 0.0 & 0.0 \\
\hline
\end{tabular}

Sources: Burkinabe authorities; and staff estimates and projections.

$\mathrm{E} / \mathrm{As}$ defined in the technical memorandum of understandias

2) Excheding HIPC initiative related-transactions.

3/ To be observed on a continuous basis. Excluding treasury notes and bonds issued in CFA frantes on the reginal WAEMU market.

4/ Excluting normal import-related credits and treasury notes and bonds issued in CFA frincs on the regional WAEMU market.

5/ For 2000, includes retroactive wage adjustrnents that have been included in wages and salaries.

6/ Excluding rêrenue collected through treasury checks.

7/For 2001 and 2002, the limits on net credit to govemment arc to be adjusted upward by the amount of the shortfall in balance of payments assistance (excluding debt relief under the HIPC Initiative);

for 2001, these adjusments are limited to a maximurn of CFAF 4 billion by end-March, CFAF 7 billion by end-June, CFAF 12 billion by end-Skptember, and CFAF 20 billion by end-December.

For 2002 , the adjuster for a shortfall in external assistance is limited to a maximum of CFAT 1 hiljion by end-March, CFAF 20 billion by end-June, CFAF 25 billion by end-September, and CFAF 30 billion at end-Decernber.

R/ Lixclending debl relief under the HiPC Isitiative. 
Table 2. Burkina Faso: Structural Benchmarks and Performance

Criteria for the 2001-02 Program

\begin{tabular}{lll}
\hline Measures & Date & Status \\
\hline $\begin{array}{l}\text { Introduce of automatic domestic price-setting mechanisms for } \\
\text { petroleum products reflecting movements in international } \\
\text { prices. }\end{array}$ & End-March 2001 & Observed \\
$\begin{array}{l}\text { Adopt of audited budget acts (Lois de règlement) from 1995 } \\
\text { End-March 2001 }\end{array}$ & Observed
\end{tabular}
to $1998 .^{1 /}$

Finalize of the interconnection of the payroll and civil service End-June 2001

Observed databases.

Set up a centralized database to track social outlays and outcomes, in particular for health and education. 1 "

End-June 2001

Observed

Securitize of the deposits of the Postal Savings Bank (CNE) with the treasury. ${ }^{\prime \prime}$

End-September $2001 \quad$ Observed

Amend the value-added tax (VAT) legislation so that credits will henceforth VAT credits offset VAT liabilities on

End-December 2001

Postponed $2 /$ receipts.

Adopt the administrative and institutional stipulations for the effective operation of the Supreme Audit Court (Cours des Comptes).

Make operational the anticorruption unit that will be independent of the government and that will have jurisdiction to investigate and review cases and to refer cases to competent judicial authorities. ${ }^{1 /}$

Eliminate of the 59 tariff lines still subject to administratively set customs values, as specified in the order No. 01-

037/MCPEA/MEF of May 28, 2001."

Appoint of three magistrates to the Supreme Audit Court. ${ }^{1 /}$

End-June 2002

Observed

${ }^{\mathrm{I}}$ Performance criterion.

${ }^{2}$ Under discussion within the West African Economic and Monetary Union (WAEMU).

${ }^{3}$ In June 2002, 26 tariff lines were eliminated; in line with a March 2002 directive of the WAEMU, an extension of the remaining 33 lines will be requested from the World Trade Organization (WTO, but the valuations on 29 of the remaining 33 lines were lowered in June 2002. 


\section{Burkina Faso: Relations with the Fund}

(As of August 31, 2002)

I. Membership Status: Joined: May 02, 1963;

Article VIII

II. General Resources Account:

Quota

Fund holdings of currency

Reserve position in Fund

II. SDR Department:

Net cumulative allocation

Holctings

IV. Outstanding Purchases and Loans:

Enhanced Structural Adjustment Facility (ESAF)/Poverty Reduction and Growth

Facility (PRGF) arrangements
SDR Million

60.20

52.95

7.25

SDR Million

9.41

0.33

SDR Million

92.55
$\%$ Quota 100.00

87.95

12.05

\%Allocation

100.00

3.51

\%Quota

153.73

V. Latest Financial Arrangements:

Approval Expiration Amount Approved Amount Drawn

\begin{tabular}{lccrrr}
\multicolumn{1}{c}{ Type } & Date & Date & (SDR Million) & (SDR Million) \\
${ } }$ & Sep. 10, 1999 & Dec. 09, 2002 & 39.12 & 33.54 \\
ESAF & Jun. 14, 1996 & Sep. 09, 1999 & 39.78 & 39.78 \\
ESAF & Mar. 31, 1993 & May. 30, 1996 & 53.04 & 44.20
\end{tabular}

VI. Projected Obligations to Fund

(SDR Million; based on existing use of resources and present holdings of SDRs):

\begin{tabular}{lrrrrr} 
& & \multicolumn{3}{c}{ Forthcoming } & \\
\cline { 3 - 5 } Principal & $\underline{2002}$ & $\underline{2003}$ & $\underline{2004}$ & $\underline{2005}$ & $\underline{2006}$ \\
Charges/interest & 5.10 & 12.60 & 13.50 & 11.70 & 10.10 \\
Total & $\underline{0.30}$ & $\underline{0.60}$ & $\underline{0.60}$ & $\underline{0.50}$ & $\underline{0.40}$ \\
\hline 5.40 & 13.20 & 14.10 & 12.20 & 10.50
\end{tabular}

\section{Latest Financial Arrangements:}

\begin{tabular}{|c|c|c|c|c|}
\hline Type & $\begin{array}{l}\text { Approval } \\
\text { Date } \\
\end{array}$ & $\begin{array}{l}\text { Expiration } \\
\text { Date } \\
\end{array}$ & $\begin{array}{l}\text { Amount Approved } \\
\text { (SDR Million) }\end{array}$ & $\begin{array}{c}\text { Amount Drawn } \\
\text { (SDR Million) }\end{array}$ \\
\hline SAF/PRGF & Sep. 10,1999 & Dec. 09,2002 & 39.12 & 11.18 \\
\hline ESAF & Jun, 14, 1996 & Sep. 09, 1999 & 39.78 & 39.78 \\
\hline ESAF & Mar. 31, 1993 & May. 30, 1996 & 53.04 & 44.20 \\
\hline
\end{tabular}


VII. Implementation of HIPC Initiative:

\begin{tabular}{|c|c|c|c|}
\hline Commitment of HIPC assistance & $\begin{array}{c}\text { Original } \\
\text { Framework }\end{array}$ & $\begin{array}{l}\text { Enhanced } \\
\text { Framework }\end{array}$ & Total \\
\hline Decision point date & Sep. 1997 & Jul. 2000 & \\
\hline Assistance committed (NPV terms) & End-1999 & End-1999 & \\
\hline Total Assistance by all creditors (USS Million) & 229.00 & 169.00 & \\
\hline Of which: IMF Assistance (SDR Million) & 16.30 & 16.74 & \\
\hline Completion point date & JuE. 2000 & Apr. 2002 & \\
\hline Delivery of Fund assistance (SDR Million) & & & \\
\hline Amount disbursed & 16.30 & 18.08 & 34.38 \\
\hline Interim assistan & & 4.15 & 4.15 \\
\hline Completion point ${ }^{2}$ & 16.30 & 13.93 & 30.23 \\
\hline $\begin{array}{l}\text { Amount applied against member's } \\
\text { obligations (cumulative) }\end{array}$ & 4.97 & 4.60 & 9.57 \\
\hline
\end{tabular}

\section{Safeguards Assessments:}

The Central Bank of West African States (BCEAO) is the common central bank of the West African states, which includes Burkina Faso. An on-site safeguards assessment of the BCEAO proposed specific remedies to alleviate vulnerabilities that were identified by the staff. Although the Fund staff and BCEAO authorities disagreed on the initial modalities of the recommendations, the following specific understandings were subsequently reached regarding the key remedies.

Financial reporting framework. The Fund staff recommended that the BCEAO formally adopt International Accounting Standards (IAS) and publish a complete set of financial statements, including detailed explanatory notes. It was agreed between the BCEAO and Fund staff that the BCEAO will strive to improve its financial and accounting reporting by aligning its practices with those recommended by IAS, as adopted internationally by other central banks.

Internal controls system. The staff noted that the absence of oversight of the bank's governance, financial reporting, and internal control practices by an entity external to the management of the $\mathrm{BCEAO}$ represented a significant risk. It was agreed between the $\mathrm{BCEAO}$ and Fund staff that, after seeking the opinion of the external auditor (Commissaire Contrôleur), BCEAO staff will propose to the BCEAO Board of Directors that it adopt a resolution whereby the external auditor will be required to apprise the Board of Directors, during its annual review and approval of the financial statements, of the state and quality of internal controls within the bank.

The staff will follow up on the progress of the BCEAO in implementing the proposed recommendations as part of the ongoing safeguards monitoring process. 


\section{Exchange Rate Arrangement:}

Starting on January I, 1999, Burkina Faso's currency, the CFA franc, has been pegged to the euro at the rate of $€ 1=\mathrm{CFAF}$ 655.96. The exchange rate on August 31, 2002 was CFAF $885.58=$ SDR 1 . The exchange system is free of restrictions on the making of payments and transfers for current international transactions.

\section{Article IV Consultations:}

Burkina Faso is on the standard 12-month consultation cycle. The 2002 Article IV discussions and the fifth review under the Poverty Reduction and Growth Facility (PRGF) were held during the period January 29-February 14, 2002 in Ouagadougou. The staff report (EBS $/ 02 / 48 ; 3 / 15 / 02)$ and the statistical annex (SM/02/84;3/15/02) were considered by the Executive Board on March 29, 2002.

\section{ROSC/AAP:}

An FAD mission visited Ouagadougou during May 7-18, 2001 to help the authorities undertake a draft fiscal module of a Report on the Observance of Standards and Codes (ROSC). The final report, which was issued in July 2002, found that Burkina Faso was making good progress in a number of areas to increase the transparency and accountability of government. But additional efforts are needed to bring a number of improvements to the point of implementation, particularly with regard to expenditure tracking at the local level and external audit functions. Initial discussions indicated that the authorities were in broad agreement with the mission assessment. On July 31, 2002, the authorities formally adopted an action plan based on the recommendations of the final ROSC.

The team, jointly with World Bank staff, also discussed as Initiative for Heavily Indebted Poor Countries (HIPC Initiative) Assessment and Action Plan (AAP) with the authorities. The aim was to assess the capacity of the public expenditure management system to track poverty-reducing public expenditures under the HIPC Initiative and the need for technical assistance to enhance that capacity. The mission secured officials' agreement with the jointly prepared preliminary assessment; identified the main needs for technical assistance the capacity to track such expenditures; and drew up a draft outline action plan. This plan identifies the main needs for further technical assistance to improve tracking of povertyreducing expenditures. The AAP has been communicated to the authorities by the staffs of the IMF and the World Bank for final endorsement.

\section{Technical Assistance:}

Significant technical assistance has been provided since 1989 , especially, more recently, in the fiscal area: 
Department

FAD

FAD

FAD

FAD

FAD
Type of Assistance Time of Delivery

Staff

October 6-17, 1997

Staff

November 20-30, 1998

Staff

February 11-25, 1999

Staff

December 4 11, 1999

May 7-18, 2001

\section{Purpose}

Assessing the fiscal impact of the common external tariff (CET) and regional integration, and defining policies to offset revenue losses.

Assessing implementation of the 1997 mission recommendations and proposing complementary reforms to strengthen the fiscal and customs administrations. Assisting in upgrading the computer system used for large taxpayers and following up on the implementation of previously recommended measures.

Monitoring the upgrading of the computer system used for large taxpayers; reviewing the establishment of a withholding system for business taxes; reviewing the system of treasury refunds of taxes due on foreign-financed. projects; and proposing modalities for eliminating valueadded tax exemptions on investments.

Assisting in completion of the fiscal module of the Report on the Observance of Standards and Codes (ROSC), and drafting an assessment of an action plan, and of the capacity of the public expenditure management system to track and report on the uses of HIPC Initiative assistance and all poverty-reducing expenditures.

\section{Resident Representative:}

Mr. Robert Franco took up the post of Resident Representative in early December 2000 


\title{
Burkina Faso: Relations with the World Bank Group
}

\author{
(As of September 24, 2002)
}

\section{The Country Assistance Strategy (Fiscal Year 2000-03)}

The general objective of the November 2000 Country Assistance Strategy (CAS) for the World Bank is to support the government's efforts, as described in the June 2000 poverty reduction strategy paper (PRSP), to achieve sustained high growth rates, to reduce the high incidence of poverty, and to improve the nutrition, health, and education of the rural population, which constitutes the largest group among the poor. The CAS has three specific objectives: (i) supporting policies and programs aimed at improving the supply side of the economy to allow for sustained, broad-based, and export-oriented growth; (ii) improving public finance management to ensure that government revenues are mobilized without distorting the modern sector of the economy; and (iii) ensuring that the allocation process and public spending effectiveness goals result in a special emphasis on social services.

The World Bank's assistance to the PRSP is intended to be selective and complementary to activities supported by other donors. Specifically, the Bank envisages a program and related country budget allocation which will (i) give priority to supervision of ongoing projects; (ii) acknowledge the important role of donors; (iii) consolidate lending operations into fewer but broader resource transfer mechanisms that are more closely integrated with the Government's own budgetary allocation and execution processes; and (iv) include a share of non-lending services to foster a robust analytical base for consensus and partnership building.

To refocus its assistance program with a consistent emphasis on rapid growth with poverty reduction, the Bank Group strategy in Burkina Faso focuses attention on (i) key social sectors where there are viable long-term strategies or where they can be developed; (ii) longer-term economic reforms to improve competitiveness and reduce business costs; (iii) improving public resource management; and (iv) adapting Bank programs to the subregional framework and potentials. Bank lending to Burkina Faso takes the form of resultsdriven programmatic credits (PRSCs) and self-standing projects for capacity building, support for Community Driven Development activities (concentrating on rural, social or HIV/AIDS interventions) and infrastructure investments directly targeted to poverty alleviation and private sector development. There is a continued commitment to analytical and advisory activities as knowledge is the critical input for progress in the substantive areas presented in the PRSP.

Assessment of Country Policies. In close collaboration with the Burkinabè authorities, IDA has undertaken a substantial body of analytic work over the past three years to assess key social, structural, and sectoral development policies and identify policy and institutional reform priorities for poverty reduction. IDA has relied on a combination of annual Policy Framework papers, a second priority poverty survey and two poverty profiles, sectoral policy notcs, and informal papers on specific issues such as constraints to growth and competitiveness, or the dynamics of poverty and income inequality. IDA has also helped the Burkinabè authorities carry out a substantial amount of analytical work in key sectors (education, health, rural development, energy, transport, and private sector development). With IDA support, the Government also carried out a comprehensive economic study on long-term sources of growth and 
competiliveness in Burkina Faso. The study was officially presented to the authorities and donors in Ouagadougou in Noveruber 2001. On poverty reduction, two further studies are planned in the near future, a Participatory Poverty Assessment (2002-03) and the Third National Household Survey (2002-03).

\section{Burkina Faso Bank Portfolio}

Since the beginning of the structural reforms in the early 1990s, the World Bank has approved, in addition to support for investment projects, two structural adjustment credits, an economic recovery credit, an agricultural sector adjustment credit, a transport adjustment credit, an economic management reform credit, and two poverty reduction support credits (PRSC 1 and PRSC 2). The World Bank's cumulative commitments to Burkina Faso, as of Scptember 24, 2002, amount to US $\$ 1,230.7$ million equivalent for 62 operations, comprising 59 IDA credits and 3 IFC investments.

The current portfolio amounts to commitments of US\$381.5 million, of which US\$290.5 million is undisbursed. IDA's active portfolio in Burkina Faso is as follows:

- The PRSC 2 was approved in July 2002 for US\$35 million. The PRSC program focuses on key sectoral action plans and reforms to improve public finance management and the competitiveness of the economy, and to facilitate the country's integration into the regional and world economy.

- Three operations support IDA's strategy in the agriculture sector. A second Agricultural Services project (US\$41.3 million, fiscal year 1998 (FY98) aims at increasing agricultural productivity and farmers' incomes, improving natural resource management, and promoting institutional development. A Private Irrigation project (US\$5.2 million, FY 99) supports provision of the demand-driven services necessary for the development of an efficient, sustainable small irrigation subsector in Burkina Faso. A Community-Based Rural Development Program (US\$66.7 million, FY 01) aims at reducing poverty and promoting sustainable development in rural areas. Its first phase provides for building local capacity to plan and implement rural development, accelerating the pace of public transfers for decentralized rural development, and supporting implementation of the country's decentralization framework.

- To support human resource development, four operations are being implemented. In education, a Basic Education operation (US\$32.6 million) was approved in January 2002 by the World Bank Board of Directors. The project supports the Government's Basic Education Ten-Year Program, which is designed to be implemented in three phases, the first of which covers the period 2001-05. The main development objective of Phase l of the Ten-Year Program is to lay the foundation for accelerating the development of basic education, while ensuring adequate quality and financial sustainability. A Post-Primary Education project (US\$26 million, FY 97) finances parts of the government's postprimary education strategy. The Bank also assists the country with the implementation of a new development learning center (US\$2.5 million, FY 03) for distance-learning activities that will give the Burkinabè 
access to the latest research worldwide. A HIV/AIDS Disaster Response project (US\$22 million, FY 02) underpins the implementation of the government's 2001-04 medium-term HIV/AIDS/STIs strategic plan, which has been endorsed by the country's technical and financial partners.

- In the urban sector, an Urban Environment project (US\$37 million, FY 95) aims at improving living conditions through priority urban works and urban services benefiting low-income groups. Under this project, supplemental financing of US\$22 million to the government's decentralization process was approved in FY 02 .

- A water supply project (US\$70 million, FY 01) aims at increasing access to adequate and reliable potable water in Ouagadougou through expanded distribution and tertiary water networks and improved urban water subsector management.

- In the mining sector, a Mining Sector Capacity Building and Environmental Management project (US\$21.4 million, FY 97) supports regulatory reform and training, institutional strengthening and resource management, environmental management, and small-scale artisanal mining.

The World Bank's proposed lending program is as follows:

- A technical assistance credit for private sector development (Competitiveness and Enterprise Development project) will be presented to the Board in FY 03 to provide support in the implementation of the residual privatization program; improve the quality, access, and cost of telecommunications; and promote the development of a strong indigenous private sector in Burkina Faso through a streamlined business environment and the provision of well-targeted financial and nonfinancial services to small and medium-sized enterprises.

- In the transport sector, the World Bank is considering a rural roads project for FY 03.

- In the energy sector, the World Bank is considering assisting the government through a possible sector reform operation (FY 03), aimed at introducing private sector participation to improve the efficiency of the provision of electricity services and the supply of bydrocarbon products to the economy, and increasing access to infrastructure services, especially for rural communities.

- A third poverty reduction support credit (PRSC 3) is envisaged for Board presentation in early FY 04. 
Statement of IDA Credits

(In millions of U.S. dollars)

\begin{tabular}{llrrr}
\hline $\begin{array}{llll}\text { Credit } \\
\text { Number }\end{array}$ & \multicolumn{1}{l}{ Fiscal } & & \\
\hline C27280-BF & Year & \multicolumn{1}{c}{ Sector } & IDA & Undisbursed \\
CN0070-BF & 1995 & Urban Environment & 59.0 & 25.9 \\
CN0290-BF & 1997 & Post-Primary Education & 26.0 & 8.1 \\
C29740-BF & 1997 & Mining Capacity Building & 21.4 & 7.7 \\
C31610-BF & 1998 & Ag. Services II & 41.3 & 20.6 \\
C34360-BF & 1999 & Private Irrigation & 5.2 & 2.1 \\
C34760-BF & 2001 & Community-Based Rural Devlpt. & 66.7 & 62.9 \\
C35570-BF & 2001 & Ouagadougou Water Supply & 70.0 & 68.2 \\
N/e & 2002 & HIV/AIDS Disaster Response & 22.0 & 21.4 \\
N/e & 2002 & Basic Education & 32.6 & 33.9 \\
N/e & 2002 & PRSC 2 & 35.0 & 37.2 \\
& 2003 & Development Learning Center & 2.3 & 2.5 \\
Total (number of credits: 11) & & 381.5 & 290.5 \\
& & & & \\
\hline
\end{tabular}

N/e: Not yet effective

Source: World Bank.

For additional information, please contact Eavan O'Halloran, Tel 473-8718 


\section{Burkina Faso: Statistical Issues}

In January 2001, Burkina Faso formally adopted the General Data Dissemination System (GDDS) as its statistical development framework, and a country coordinator has been named. During the GDDS workshop in Bamako in March-April 2001, draft GDDS metadata were prepared for all five sectors, including plans for improvements, and were posted on the data Standard Bulletin Board (DSBB) in December 2001. Following the conversion of the Statistical Institute into an autonomous agency, its allocations in human and material resources were significantly raised in the 2002 budget.

\section{Real sector}

Serious problems have been identified both in the area of national accounts and price statistics. While the general framework of the national accounts is rather complete, there are substantial problems with the source data for the national accounts at current prices and the prices used as deflators. In particular, the industrial production index should be updated to include new industrial units. Also, the procedure to collect information on private investment and services should be improved. A new household survey completed in 1999 provides detailed information on the incidence of poverty and expenditure patterns. In addition, the national accounts suffer from methodological problems.

The base year for the constant price national accounts estimates has been updated from 1979 to 1985 , resulting in revisions in the data from 1985 onward. The final 1993-97 national accounts were published in May 2000. The index of industrial production is under review, within the framework of a program harmonized at the level of the West African Economic and Monetary Union (WAEMU); the last industrial census, conducted in March 1998, will be used in the construction of the new index.

A new consumer price index was published in 1998, based on a survey undertaken in the context of a regional project financed by the European Union and France. The coverage of this index will gradually be extended to include markets outside Ouagadougou.

\section{Government finance}

The last summary annual data published in International Financial Statistics (IFS) are for 2000. No detailed data have been reported for the past five years to STA; hence, the 2000 Government Finance Statistics (GFS) Yearbook covers only 1984-93, with limited details and coverage (and the data relate only to budget operations and capital expenditures financed through grants. No data are reported on extrabudgetary and social security operations, as well as on operations financed by foreign loans). The compilation of $G F S$ is constrained by a lack of coordination among fiscal agencies, which has a negative impact on the reliability and timeliness of these data. 


\section{Monetary accounts}

Preliminary monetary data for Burkina Faso are prepared by the national agency of the Central Bank of West African States (BCEAO) and released officially by the headquarters of the BCEAO with a lag of two to three months. An accounting system for commercial banks was introduced by the BCEAO on January 1, 1996. Most of the problems that appear in the monetary statistics for Burkina Faso are not specific to that country but concern all countries of the WAEMU. ${ }^{1}$ One statistical problem arises from the difficulties the BCEAO has encountered in estimating currency in circulation in each WAEMU member country because of the large backlog of unsorted banknotes held by the central bank in its various national agencies. A money and banking statistics mission visited the BCEAO in August 1997, investigated these problems, and reviewed with the authorities several measures that would contribute to reducing the delay. The $\mathrm{BCEAO}$ is working on additional measures to accelerate the sorting operations in order to resolve this problem.

A second problem has been the slower-than-expected implementation of the new accounting system by banks since its introduction in 1996. These delays contribute importantly to the lag in reporting monetary statistics. The August 1997 STA mission that visited the BCEAO recommended that timing targets for reducing delays in producing the principal report forms be established. The situation has improved recently, and data for the monetary authorities and deposit money banks have been provided to STA on a more regular basis. While there has been a recent reduction in the lag in reporting monetary data to STA, among others--and this appears to reflect in part an acceleration in this phase of statistical production-there is scope for further improvement.

A monetary and financial statistics mission visited the headquarters of the BCEAO in May 2001. The mission reviewed the procedures for collecting and compiling monetary statistics, and addressed the outstanding methodological issues that concern all the member countries of the WAEMU. The authorities agreed on an action plan for the implementation of the Monetary and Financial Statistics Manual and on the introduction of an area-wide page for the WAEMU in the IFS, which is in the preparatory stage. The mission discussed provision of future technical assistance in monetary statisties for the region.

\section{Balance of payments}

Since December 1998, the responsibility for compiling and disseminating balance of payments statistics has been formally assigned to the BCEAO through area-wide legislation adopted by the countries composing the union. The national agency of the BCEAO is responsible for completing and disseminating the balance of payments statement, while the BCEAO headquarters delineates the methodology and calculate the international reserves

\footnotetext{
${ }^{1}$ Benin, Burkina Faso, Côte d'Ivoire, Guinea-Bissau, Mali, Niger, Senegal, and Togo.
} 
managed on behalf of the participating countries. The data consistency have significantly improved over the past few years, with a full transition to the Balance of Payments Manual, fifth edition (BPM5), improved sourcing methods and the training of staff. This improvement was supported by technical assistance provided by STA (Statistical Advisor from July 1996 through July 1999 posted at the BCEAO headquarters in Dakar) and contributed to the reporting of better yearly balance of payments data in the framework of the BPM5 for the period 1996-99. This improvement, coupled with the backward revision of data to 1988, has created a consistent series for anmual balance of payments statistics. The BCEAO national agency disseminates balance of payments statistics with a seven-month lag, and annual international investment position data with an 18-month lag, in full consistency with the recommendations of the GDDS guidelines. Regarding trade data, the customs computer system (SYDONLA) was upgraded in 1999, and its installation in the main border customs houses is complete; this allows for a better monitoring of import data and should improve the coverage of informal trade. The further improvement of services and transfers (especially workers' remittances) coverage is clearly linked to the future intensification of the contacts with reporting bodies; this implies that the authorities' commitment to strengthen the human and technical resources should be enhanced.

Concerning the financial account, the foreign assets of the private nonbanking sector are still not well covered, especially the assets of WAEMU residents, which are obtained through the Bank for International Settlement (BIS) data. The organization of annual exhaustive surveys for the reporting of foreign direct investment transactions in Burkina Faso is still at a preliminary stage. The $\mathrm{BCEAO}$ authorities have indicated that they are looking forward to integrating two additional sources aimed at improving the quality of the balance of payments reports: the regional stock exchange transactions, and the firms ${ }^{*}$ balance sheet database (centrale des bilans). They have also indicated that quarterly data derived from banking settlements reports will soon be used to assess the existing information. In addition, the $\mathrm{BCEAO}$ has recently implemented a compilation system allowing commercial banks to report data on payments involving nonresidents. The balance of payments compilers receive payment statements every ten days; however, the information is not used in the compilation of the annual balance of payments statements but to rather support data quality controls and to provide early information to the BCEAO authorities.

The follow-up mission at the BCEAO headquarters (April 17-28, 2000) highlighted improvements in published data. However, the mission pointed out serious shortages in the human and technical resources that were hampering the implementation of the statistical advisor's recommendations.

The computer debt-management system software, SYGADE, developed by the United Nations Conference on Trade and Development (UNCTAD), was introduced in 1999 and is fully operationaI. Information on debt disbursement has also been fully integrated with the expenditure monitoring system. 
Burkina Faso: Core Statistical Indicators

(As of October 8, 2002)

\begin{tabular}{|c|c|c|c|c|c|c|c|c|c|c|c|c|}
\hline & $\begin{array}{l}\text { Exchange } \\
\text { Rates }\end{array}$ & $\begin{array}{c}\text { International } \\
\text { Reserves }\end{array}$ & $\begin{array}{c}\text { Reservel } \\
\text { Base } \\
\text { Money }\end{array}$ & $\begin{array}{l}\text { Central } \\
\text { Bank } \\
\text { Balance } \\
\text { Sheet }\end{array}$ & $\begin{array}{l}\text { Broad } \\
\text { Money }\end{array}$ & $\begin{array}{l}\text { Interest } \\
\text { Rates } 1 /\end{array}$ & $\begin{array}{l}\text { Consumer } \\
\text { Price } \\
\text { Index }\end{array}$ & $\begin{array}{l}\text { Exports! } \\
\text { Imports } 2 /\end{array}$ & $\begin{array}{l}\text { Current } \\
\text { Account } \\
\text { Balance }\end{array}$ & $\begin{array}{c}\text { Overall } \\
\text { Govcra- } \\
\text { ment } \\
\text { Balance }\end{array}$ & GDP/GNP $3 /$ & $\begin{array}{c}\text { External } \\
\text { Debt }\end{array}$ \\
\hline $\begin{array}{l}\text { Date of latest } \\
\text { Observation }\end{array}$ & July 2002 & Junc 2002 & June 2002 & June 2002 & Jane 2002 & Aug. 2002 & July 2002 & May 2002 & Dec. 2001 & Iunc 2002 & 2001 & Dec. 2001 \\
\hline Date received & July 2002 & Sept 9,2002 & Sept. 9, 2002 & Sept. 9, 2002 & Sept. 9,2002 & Sept. 9, 2002 & Oct. 2002 & Oct. 2002 & Feb. 2002 & July 2002 & Fet. 2002 & $\begin{array}{l}\text { March } \\
2002\end{array}$ \\
\hline Frequency of data & Daily & Monthly & Monthly & Monthly & Monthly & Monthly & Monthly & Monthly & Annual & Monthly & Antually & Antnual \\
\hline $\begin{array}{l}\text { Frequcncy of } \\
\text { reporting }\end{array}$ & Daily & Monthly & Monthly & Monthly & Monthly & Monthly & Monthly & Quarterly & Annually & Monthly & Annually & Annually \\
\hline Source of data 4/ & EIS/TRE & BCEAO & BCEAO & ВСЕАO & BCEAO & BCE $\Lambda O$ & BCEAO & BCEAO & BCEAO & $\begin{array}{l}\text { Ministry of } \\
\text { Finance }\end{array}$ & $\begin{array}{l}\text { Ministry of } \\
\text { Finance }\end{array}$ & $\begin{array}{c}\text { Ministry of } \\
\text { Finatce }\end{array}$ \\
\hline Mode of reporting & On-line & Staff/e-mail & Staff/e-mail & Staff/e-mail & Staffle-mail & Stafffe-mail & Flectronic & Flectronic & Stat $]^{\top}$ & StalT & Stalf & Staff \\
\hline Confidentiality & No & $5 /$ & 57 & $5 /$ & $5 /$ & No & No & $5 /$ & $5 t$ & 5 & $5 /$ & 5 \\
\hline $\begin{array}{l}\text { Frequency of } \\
\text { publication }\end{array}$ & Daily & Monthly & Monthly & Monthly & Monthly & Monthly & Monthly & Annually & Annually & Monthly & Annually & Annually \\
\hline
\end{tabular}

1/ Up-to-date data available upon request from BCEAO; also updated regularly in press.

2/ Customs data available monthly in conjunction with fescal data.

3/ Revised periodically during year.

4/ EIS = IMF, Economic Information System; TRE = IMF, Treasurer's Department; BCEAO = Central Bank of West Affican States.

5. Preliminary use for staff only: actual data unrestricted. 


\section{Burkina Faso: Elements of a Successor Program That Could Be Supported by a Three-Year PRGF Arrangement}

\section{A. Underlying Economic Features}

Account would need to be taken of the following economic features:

- relatively good growth performance since the 1994 devaluation, except for 2000 , because of drought;

- prudent macroeconomic and fiscal policies;

- very low social/human development indicators-Burkina Faso was ranked $159^{\text {th }}$ out of 162 in the 2001 United Nations Development Program (UNDP) human development index;

- high incidence of poverty, in particular in rural areas-according to the most recent national household survey (carried out in 1998), 45.3 percent of the population live below the poverty line;

- narrow resource base, reflected in a large primary sector (36.5 percent of GDP in 2001), significant dependence on cotton, and small formal economy, which makes the economy extremely vulnerable to external shocks;

- high energy costs-Burkina Faso's landlocked position and delays in privatizing of the electricity company, SONABEL, and in pursuing the interconnection with neighboring countries results in high electricity tariffs; and

- administrative red tape hindering private sector activity.

\section{B. Draft Strategy Framework for a New Arrangement with Burkina Faso}

Primary objectives of the program should be as follows:

- Maintain high growth in a stable macroeconomic environment.

- Ensure high rate of income growth of the poor (primarily the rural poor) and improve social indicators.

\section{Intermediary/supporting objectives (policies)}

The following list, which may include additional policies, should be prioritized and sequenced based on an assessment of economic as well as political constraints after discussion with the authorities: 
- A sound fiscal policy, improved fiscal transparency, and governance should be part of the framework, to ensure continued fiscal prudence to buttress macroeconomic stability, increased income generation capacity of the poor, and better tracking of (i) fiscal expenditure, to ensure that exante prioritization of expenditures has actually been implemented, and (ii) social outcomes. With respect to the latter, possible problems with absorption capacity should be studied.

- Structural reforms to sustain tax revenue should be an objective. The successor program should consider what is needed to achieve a tax revenue level of 16 to 17 percent of GDP; fiscal culture; the definition and taxation of the informal sector; the whole issue of exemptions; the technical assistance needed to improve fiscal administrations; and implementation of the action plan combining the recommendations of the Budget Management Improvement Plan (PRGB), Report on Observance of Standards and Codes (ROSC), and Country Financial Accountability Assessment (CFAA).

- The Treasury should be reformed: this includes the payment of wages and salaries, the streamlining of the accounts held at the treasury, and domestic debt management.

- The economy should be diversified to enable sustained growth (the World Bank should be in the lead). The framework should take into account the progress achieved in agricultural diversification toward higher-value products; the development of industrial sector, essentially based on agro-industry (including textiles), and development of services; bright spots and bottlenecks; and necessary conditions for increasing investments (including further disengagement of the state from productive sectors).

- Decentralization policies should be part of the framework, with attention given to comparative advantages of decentralization and decentralized fiscal policies.

- Product market reforms are needed (with the World Bank in the lead). In particular, further liberalization and reform in the energy sector; total liberalization of petroleum products market (this needs further analysis); and further cotton sector reform are required.

- Private financial savings should be encouraged and financial intermediation increased, by improving the penetration rate of commercial banks and dismantling barriers to credit; and further developing a sound microfinance sector.

- Administrative red tape should be reduced (with World Bank in the lead). 


\section{NTER NATIONAL MONETARY FUND}

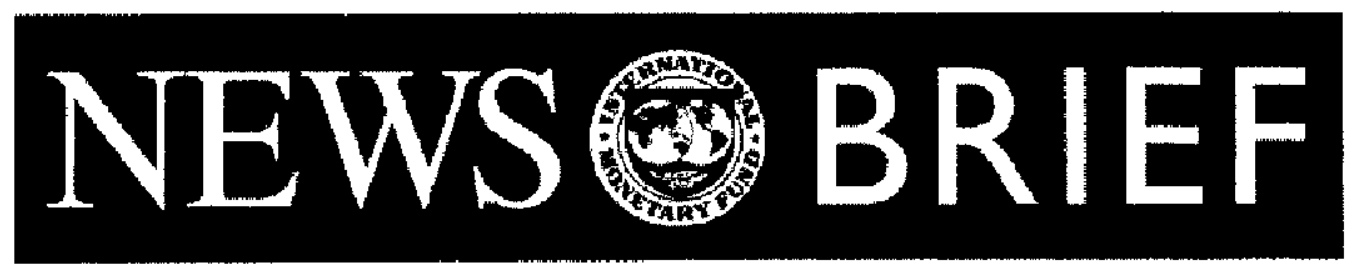

FOR IMMEDIATE RELEASE

News Brief No. 02/113

FOR IMMEDIATE RELEASE

November 13, 2002
International Monetary Fund

70019 th Street, NW

Washington, D. C. 20431 USA

\section{IMF Completes Review Under Burkina Faso's PRGF Arrangement and Approves US\$7 Million Disbursement}

The Executive Board of the International Monetary Fund (IMF) today completed the sixth review of Burkina Faso's economic performance under the Poverty Reduction and Growth Facility (PRGF) arrangement. As a result, Burkina Faso will be able to draw up to SDR 5.58 million (about US $\$ 7$ million) under the arrangement immediately.

The Executive Board also waived Burkina Faso's non-observance of the end-June 2002 performance criteria on the cumulative change in total net domestic budget financing and on the elimination of the 59 administratively set customs valuations existing as of May 28, 2001.

Burkina Faso's program was originally supported by a three-year arrangement under the Enhanced Structural Adjustment Facility (ESAF) approved on September 10, 1999 (see Press Release 99/42), for SDR 39.12 million (about US\$52 million). So far, Burkina Faso has drawn SDR 33.54 million (about US\$45 million).

The PRGF is the IMF's concessional facility for low income countries. It is intended that PRGF-supported programs are based on country-owned poverty reduction strategies adopted in a participatory process involving civil society and development partners, and articulated in a Poverty Recuction Strategy Paper (PRSP). This is intended to ensure that each PRGF-supported program is consistent with a comprehensive framework for macroeconomic, structural, and social policies to foster growth and reduce poverty. PRGF loans carry an annual interest rate of 0.5 percent, 
and are repayable over 10 years with a $51 / 2$-year grace period on principal payments.

After the Executive Board's discussion on Burkina Faso, Shigemitsu Sugisaki, Deputy Managing Director and Acting chairman, stated:

"Implementation of Burkina Faso's PRGF-supported program remains satisfactory in 2002. Macroeconomic policies and structural reforms have been supportive of economic growth and stability. Prudent management of the cotton sector and efforts to lower energy costs, promote good governance and judiciary reform, strengthen financial intermediation, improve budget management, and develop human capital bode well for sustaining strong economic growth in 2002 and the medium term. However, the recent crisis in Côte d'lvoire, if not resolved soon, could have some adverse impact.

"Continued fiscal consolidation will be central to sustaining macroeconomic stability and economic growth. Therefore, authorities are encouraged to sustain their efforts to broaden the tax base and improve tax administration, which contributed to an increase in tax revenue in the first half of 2002. To offset expenditure overruns in the first half of 2002, non-essential spending needs to be contained in the second half of the year. Consideration could perhaps be given to reducing subsidies on petroleum for electricity generation. Revenue increases, together with expenditure restraint, will ensure that the necessary budgetary savings are generated to finance infrastructure investment and poverty reduction programs.

"The authorities have been steadfastly pursuing the objectives embedded in the poverty reduction strategy paper, and have prepared a second annual progress report on PRSP implementation. After a slow start in 2000 and 2001, utilization of HIPC Initiative resources accelerated significantly in the first half of 2002. Nevertheless, a stronger effort needs to be made to increase the effectiveness of spending in the health and education sectors, address remaining institutional weaknesses and infrastructure bottlenecks that limit absorptive capacity, strengthen the linkages between the PRSP and the budget process, broaden the PRSP participatory process, and improve the tracking of social outcomes.

"There has been a delay in agreeing on the precise modalities for creditor participation in the topping-up assistance granted to Burkina Faso under the HIPC Initiative, and the process needs to be accelerated. Other 
multilateral and non-Paris Club creditors are urged to participate fully in the HIPC Initiative for Burkina Faso.

"The authorities intend to embark on a successor economic program that the Fund could support to consolidate the achievements of the current program in the present uncertain external environment. The new program should focus on accelerating economic growth and diversification, and strengthening the fiscal framework," Mr. Sugisaki stated. 